\title{
GAMAESPECTROMETRIA, RESISTIVIDADE ELÉTRICA E SUSCEPTIBILIDADE MAGNÉTICA DE SOLOS AGRÍCOLAS NO NOROESTE DO ESTADO DO PARANÁ
}

\author{
Valter Antonio Becegato ${ }^{1,2}$ e Francisco José Fonseca Ferreira ${ }^{2}$ \\ Recebido em 07 julho, 2005 / Aceito em 16 dezembro, 2005 \\ Received on July 07, 2005 / Accepted on December 16, 2005
}

\begin{abstract}
Gamma-ray spectrometry, electrical resistivity, and magnetic susceptibility measurements were taken from agricultural areas near the City of Maringá, in the Northwest region of the Paraná state, south Brazil, in order to characterize the spatial distribution of radionuclides (K, eU, and eTh), the apparent resistivity, and the magnetic susceptibility determined for soils. Three different types of soils are present in this agricultural area: Alfisoil, clayey texture Oxisoil, both deriving from Lower Cretaceous basalts of the Serra Geral Formation; and medium texture Oxisoil from reworked Serra Geral and Goio-Erê formations, the latter deriving from sandstones of the Upper Cretaceous Caiuá Group. It could be observed that in more clayey soils both concentration of radionuclides and susceptibility values are higher than in more sandy soils, especially due to the higher adsorption in the former and to the higher availability of magnetic minerals in the latter. The average ppm and $\mathrm{Bq} \mathrm{Kg}{ }^{-1} \mathrm{grades}$ for $\mathrm{K}$, eU, and eTh in the areas under anthropic activity are of 1766-54.75, 0.83-10.22, and 1.78-7.27, respectively. These grades are significantly higher than those of non-occupied or non-fertilized areas (1101-34.15 K, 0.14-1.69 eU, and 1.31-5.36 eTh in ppm and Bq Kg${ }^{-1}$, respectively.) Correlations were observed between uranium and clay, uranium and magnetic susceptibility, uranium and organic matter, and between electric resistivity and clay grades. Varied concentrations of radionuclides were also observed in different fertilizer formulations applied to soy and wheat cultures. Apparent electric resistivity values between 25 and $6470 \mathrm{hm}$.m and magnectic susceptibility values between 0.28 e $1.10 \times 10^{-3}$ SI due to clay and magnetic minerals represented important soil discrimination factors in the study area that can be incorporated as easy, low-cost soil mapping tools.
\end{abstract}

Keywords: Gamma-ray spectrometry, electrical resistivity, magnetic susceptibility, agriculture, soils, fertilizers.

RESUMO. Medições gamaespectrométricas, de resistividade elétrica e de susceptibilidade magnética foram tomadas em solos agrícolas situados próximos a cidade de Maringá, noroeste do estado do Paraná, sul do Brasil, objetivando caracterizar a distribuição espacial das concentrações de radionuclídeos (K, eU e eTh), da resistividade aparente e da susceptibilidade magnética. Na área agrícola ocorrem três tipos de solos: Nitossolo Vermelho Eutrófico, Latossolo Vermelho Eutroférrico textura argilosa, ambos derivados da Formação Serra Geral (basaltos do Cretáceo Inferior) e Latossolo Vermelho Distrófico textura média, oriundo do retrabalhamento das formações Serra Geral e Goio-Erê, esta última composta por arenitos do Grupo Caiuá (Cretáceo Superior). Constatou-se que as concentrações de radionuclídeos e os valores de susceptibilidade magnética nos solos mais argilosos foram maiores do que nos solos mais arenosos, em função, principalmente, da maior adsorção dos primeiros e da maior disponibilidade de minerais magnéticos. Os teores médios em ppm e $\mathrm{Bq} \mathrm{Kg}^{-1}$ de $\mathrm{K}$, eU e eTh na área com atividade antrópica foram respectivamente de 1766-54,75; 0,83-10,22 e 1,78-7,27, significativamente maiores do que em áreas virgens sem aplicação de fertilizantes (1101-34,15 de K; 0,14-1,69 de eU e 1,31-5,36 de eTh, respectivamente em ppm e $\mathrm{Bq} \mathrm{Kg}^{-1}$ ). Houve correlações entre os teores de urânio e argila, urânio e susceptibilidade magnética, urânio e matéria orgânica e entre resistividade elétrica e argila. Foram também observadas variações nas concentrações de radionuclídeos em diferentes formulações de adubos utilizados nas culturas de soja e trigo. A resistividade elétrica aparente, cuja magnitude variou de 25 a 647 Ohm.m, e a susceptibilidade magnética, com oscilações entre 0,28 e $1,10 \times 10^{-3}$ SI, decorrentes dos teores de argila e de minerais magnéticos, respectivamente, se mostraram importantes na discriminação dos solos na área de estudo, podendo ser incorporadas como ferramentas rápidas e de baixos custos no mapeamento sistemático de solos.

Palavras-chave: Gamaespectrometria, resistividade elétrica, susceptibilidade magnética, agricultura, solos, fertilizantes.

\footnotetext{
1 Universidade do Estado de Santa Catarina-UDESC, Centro de Ciências Agroveterinárias, Av. Luís de Camões, 2090; Caixa Postal 281, 88520-000 Lages, SC, Brasil. Tel: (49) 3222-2277; Fax: (49) 3223-0198 - E-mail: becegato@cav.udesc.br

2Universidade Federal do Paraná-UFPR, Laboratório de Pesquisas em Geofísica Aplicada - LPGA, Centro Politécnico, Jardim das Américas, Caixa Postal 19045, 81531-980 Curitiba, PR, Brasil. Tel/Fax: (41) 3361-3132 - E-mail: francisco.ferreira@ufpr.br
} 


\section{INTRODUÇÃo}

A agricultura moderna usa de alta tecnologia, objetivando aumentar a produtividade. Culturas como a soja e o trigo empregam cultivares com grande potencial genético, que aliado a insumos como os adubos, se exteriorizam na forma de altas produtividades. Não se pode imaginar a agricultura brasileira dos últimos 20 anos, sem aplicações de grandes volumes de adubos. A presença de radionuclídeos em fertilizantes fosfatados (Guimond \& Hardin, 1989; Khan et al., 1998; Zielinski et al., 2000; San Miguel et al., 2003) traz interferências no meio ambiente, cujas conseqüências ainda são pouco conhecidas.

Recentemente tem-se utilizado o gesso, que é um subproduto da fabricação dos adubos acidulados. 0 gesso agrícola (sulfato de cálcio di-hidratado), derivado do ácido fosfórico, contém em sua composição cálcio, enxofre e água em diferentes concentrações. 0 uso deste produto tem por objetivo suprir os solos com cálcio e enxofre nos horizontes mais profundos, propiciando às plantas 0 desenvolvimento do sistema radicular, explorando maior volume de solos na busca por nutrientes e água (Nuernberg et al., 2002).

Os adubos e o gesso comercializados no Brasil encerram também elementos radioativos (e.g. Mazzilli et al., 2000; Yamazaki \& Geraldo, 2003; Saueia et al., 2004), cujos teores dependem da rocha utilizada para o seu fabrico. Especificamente quanto aos adubos fosfatados, diversas são as marcas e formulações comerciais envolvendo teores variados de nitrogênio, fósforo e potássio. Pfister et al. (1976) observaram que a elevada concentração do urânio em superfosfato triplo, em relação ao super simples, depende do modo de fabricação. No primeiro caso, a rocha sofre um ataque com ácido fosfórico, retendo o urânio na forma de um complexo uranil dissolvido. Com relação aos monoamônio fosfatos e diamônio fosfatos, estes são obtidos pela composição entre ácido fosfórico e amônio.

Os solos brasileiros, em sua grande maioria inseridos em regiões tropicais, são, em geral, pobres como decorrência de perdas constantes por lixiviação de elementos químicos como nitrogênio, fósforo e potássio, essenciais para grandes culturas como soja, trigo e cana-de-açúcar.

A forma conhecida, até o momento, de repor nutrientes aos solos e, conseqüentemente, fornecer às plantas insumos visando a obtenção de altas produtividades é por adubação química, através de compostos denominados comercialmente de formulações NPK. Tais formulações são muito variadas nos conteúdos dos elementos retromencionados, cujas concentrações variam de acordo com a necessidade de cada solo e cultura.
Os solos diferem na sua capacidade de retenção de cátions. A capacidade de troca de cátions (CTC) depende da textura, das propriedades físicas, dos teores de argila e do conteúdo de matéria orgânica. Solos mais argilosos retém mais cátions, ao contrário dos arenosos, onde nestes a percolação de água é mais rápida em função da maior macroporosidade, promovendo a lixiviação de elementos químicos que se encontram na solução do solo.

Em função do grande aporte de fertilizantes utilizados no Brasil, trabalhos pioneiros como os de Ferreira et al. (1997), Souza et al. (1997) e Souza (1998), procuraram investigar as relações de anomalias aerogamaespectrométricas de K, eU e eTh com fertilizantes fosfatados utilizados na agricultura, além de outras variáveis (processos pedogenéticos, solos, formações superficiais, geologia, susceptibilidade magnética e relevo). Neste sentido, as pesquisas geofísicas de radionuclídeos em solos agrícolas ainda são muito incipientes no Brasil. 0 presente trabaIho pretende mostrar uma aplicação da gamaespectrometria, da resistividade elétrica e da susceptibilidade magnética em área experimental localizada no município de Igaraçu-PR, cultivada com soja no verão e trigo no inverno, cujos solos variam de textura argilosa à mista, respectivamente oriundos da Formação Serra Geral e dos produtos do retrabalhamento desta com a Formação GoioErê (Grupo Caiuá), assim como discutir a contaminação de solos agrícolas derivada do uso intensivo e continuado de fertilizantes fosfatados. Nesta mesma linha, Nascimento (2003) e Nascimento et al. (2004) pesquisaram as relações entre gamaespectrometria, resistividade elétrica e solos, porém em áreas virgens sob cerrado nativo no Distrito Federal.

\section{RADIOATIVIDADE EM FERTILIZANTES FOSFATADOS E GESSO AGRÍCOLA}

Pesquisas recentes no Brasil com elementos radioativos derivados de diferentes formulações de adubos, começam a despertar 0 interesse da comunidade científica nacional no que concerne às suas implicações ambientais.

A preocupação com elementos radioativos em rochas fosfáticas iniciou-se em 1908 (Ring, 1977), quando 0 inglês R. Strutt constatou que os teores em amostras de fosforitas eram algumas vezes maior do que a média em outras rochas (Guimond, 1978). Segundo este último autor, aplicações de superfosfato simples e ácido fosfórico culminam em aporte significativo de ${ }^{226} \mathrm{Ra}$ e ${ }^{238} \mathrm{U}$.

Pfister et al. (1976), utilizando técnicas gamaespectrométricas em fertilizantes fosfatados comercializados na Alemanha, observaram que a maioria dos fertilizantes possuía teores signifi- 
cativos de urânio, cujos fosfatos processados naquele país eram importados da África e dos Estados Unidos (Flórida).

Spalding \& Exner (1976), estudando a variação temporal de urânio no rio Brazos (EUA), mostraram que o acúmulo de urânio é oriundo de fertilizantes fosfatados. 0 vale do referido rio, considerado um pólo agrícola americano, encerrou valores de 0,6 a 2,7 ppm de urânio por litro, cujos teores foram comparados com os de amostras coletadas entre 1961 e 1962, as quais indicaram índices médios de 0,4 ppm de U/L.

Segundo Rothbaum et al. (1979), a apatita contida nos adubos fosfatados é atacada pelo ácido sulfúrico durante 0 fabrico dos superfosfatos e 0 urânio permanece como sulfato de uranila $\left[\left(\mathrm{UO}_{2} \mathrm{SO}_{4}\right)\right]$ e sulfato uranoso $\left[\mathrm{U}\left(\mathrm{SO}_{4}\right)_{2}\right]$.

Zielinski et al. (1997), detectaram altas concentrações de urânio dissolvido nas áreas agrícolas irrigadas no sudoeste do Colorado (EUA), concluindo que a presença do radionuclídeo tinha origem nos fertilizantes fosfatados.

San et al. (1999), investigando a radioatividade em rochas fosfáticas no Sudão, observaram que para dois tipos de rocha (Uro e Kurun), havia teores diferenciados de $\mathrm{U}$ e Th, cujos valores médios foram $393,1 \mathrm{~Bq} \mathrm{Kg}^{-1}$ e 6,9 $\mathrm{Bq} \mathrm{Kg}^{-1}$, respectivamente.

Righi et al. (2000) obtiveram valores de U e Th em amostras de adubos fosfatados (super triplo), cujas amplitudes foram de 948,3 até $1783,5 \mathrm{~Bq} \mathrm{Kg}^{-1}$ e de 15,87 até $237,69 \mathrm{~Bq} \mathrm{Kg}^{-1}$ respectivamente; para 0 mono amônio fosfato determinaram 734,3

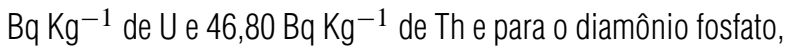
os valores detectados foram $949,56 \mathrm{~Bq} \mathrm{Kg}^{-1}$ de $\mathrm{U}$ e $74,88 \mathrm{~Bq}$ $\mathrm{Kg}^{-1}$ de Th.

Zielinski et al. (2000) conduziram outro trabalho nos Everglades da Flórida (EUA), objetivando detectar radionuclídeos nas águas dos rios e lagos daquela região, e constataram que os teores de $\mathrm{U}$ estavam acima da normalidade, concluindo que tais teores estavam relacionados com a atividade agrícola nas áreas vizinhas.

Ogunleye et al. (2002), pesquisando a presença de metais pesados e radioatividade em rochas fosfatadas de Sokoto na Nigéria, concluíram que as mesmas tinham um teor médio de $732 \mathrm{~Bq} \mathrm{Kg}^{-1}$ de urânio.

San Miguel et al. (2003), investigando concentrações de radionuclídeos nas águas do estuário entre a confluência dos rios Odiel e Tinto na Espanha, em cujo local muitas empresas de fertilizantes se instalaram nos anos 60 , constataram que houve aumento significativo de radioelementos oriundos das rochas fosfáticas e dos depósitos de gesso, carreados para os rios por erosão laminar.

\section{GEOQUÍMICA DOS RADIOELEMENTOS NO MEIO AMBIENTE \\ Urânio}

0 urânio ocorre em baixa concentração na crosta terrestre (aproximadamente 3 ppm), sendo quimicamente dominado por seus estados de valência $\mathrm{U}^{+4} \mathrm{e} \mathrm{U}^{+6} .0$ primeiro estado geralmente está contido em minerais não solúveis, enquanto o segundo associase com ânions nos carbonatos, sulfatos e fosfatos para formarem espécies solúveis (Dickson \& Scott, 1997). A mobilidade do U+6 é modificada pela adsorção a óxidos hidratados de ferro, minerais de argila e colóides, como também pela transformação em minerais de $\mathrm{U}^{+4}$ nos ambientes redutores. Nas rochas o urânio ocorre como óxidos e silicatos, uraninita e uranotorita, e, principalmente, em minerais como a monazita, o xenotímeo e 0 zircão.

0 clima quente e úmido reúne as condições necessárias para a lixiviação do urânio das rochas. Neste tipo de clima a grande circulação de águas, em geral ácidas, com oxigênio e dióxido de carbono dissolvidos, é determinante para que os minerais contendo $\mathrm{U}$, exceto os refratários, sejam hidrolisados, oxidados e lixiviados na forma do íon hidroxila $\left(\mathrm{UO}_{2}\right)^{2+}$, que em ambiente oxidante tem alta mobilidade, passando para a solução do solo (Weidjen \& Weidjen, 1995).

Souza (1998), estudando os solos da Quadrícula de Araras no estado de São Paulo, concluiu que os resultados radioquímicos de urânio nas amostras de solos foram superiores aos obtidos por Rothbaum et al. (1979), em pesquisa sobre acumulação de urânio em solos adubados com fosfatos por mais de 80 anos.

\section{Tório}

Segundo Dickson \& Scott (1997) 0 tório pode correr em alanita, monazita, xenotímeo e zircão, em concentrações maiores que 1000 ppm ou em quantidades-traço em outros minerais constituintes das rochas. Os principais minerais que contém Th (monazita e zircão) são estáveis durante o intemperismo e podem acumular-se em depósitos de minerais pesados. 0 tório liberado durante 0 intemperismo, pode ser retido em óxidos e hidróxidos de Fe e Ti e em argilas. Da mesma forma que o $\mathrm{U}, 0$ Th pode também ser transportado quando adsorvido em colóides argilosos e óxidos de ferro.

Rebello (2000) pesquisando modelos sobre rochas graníticas, comenta que 0 Th decorrente de sua baixa mobilidade geoquímica, permanece fixo durante 0 intemperismo e a pedogênese. Evidências da sua baixa solubilidade se refletem no equilíbrio com seus produtos de decaimento e em suas baixas concentrações na solução do solo; no entanto, 0 Th pode ser mo- 
bilizado em condições específicas de pH, sobretudo na presença de ácidos húmicos.

Dickson \& Scott (1997), mostraram em zonas alteradas a partir de rochas ígneas intrusivas e extrusivas, intermediárias e básicas, variações significativas na interface saprolito-solo. Tais mudanças refletem as perdas de $\mathrm{K}$ dos feldspatos potássicos e das micas e a retenção do U e do Th em óxidos de ferro e argilas ou em minerais resistatos. De modo geral, os dioritos não são facilmente distinguíveis dos basaltos, pois ambos mostraram retenção de U e Th durante a pedogênese. Ainda de acordo com tais autores, o intemperismo em rochas intrusivas intermediárias, revela que não existem mudanças significativas nos teores de radioelementos até a pedogênese, mas geralmente indicam variações abruptas nas concentrações de U e Th na interface saprolito-solo. Os dioritos apresentam um comportamento semelhante aos basaltos, os quais mostram um incremento de $\mathrm{U} e \mathrm{Th}$ durante a pedogênese.

\section{Potássio}

As ocorrências mais comuns são observadas em minerais como os feldspatos potássicos (aproximadamente $13 \%$ de K) e micas (biotita/muscovita com 8\% de K), comuns em rochas ácidas (granitos, riolitos, etc.). Teores menores são encontrados em basaltos e muito baixos em dunitos e peridoditos (Dickson \& Scott, 1997). Em função de sua solubilidade, o comportamento intempérico dos minerais potássicos determina sua depleção em rochas intemperizadas e solos.

Souza (1998), concluiu que as contagens de $K$ na frente de lavra de soleiras de dolerito, são bem mais elevadas quando comparadas com a média verificada nos Latossolos Roxos. De acordo com a autora, isto provavelmente se deva ao intemperismo, onde nota-se uma depleção do K nos solos mais desenvolvidos. Já 0 incremento deste radionuclídeo nas porções mais baixas do terreno (aluviões), pode ser explicado pela migração a partir de outras litologias.

\section{GEOQUÍMICA DOS SOLOS Mineralogia dos solos tropicais}

0 solo é constituído de minerais e poros ocupados por ar, água e material orgânico. A fração mineral, de acordo com Giannini \& Riccomini (2001), pode ser constituída de partículas de tamanhos variáveis, desde argila (partículas menores que 0,004 mm) até matacões (superiores a $256 \mathrm{~mm}$ ).

Com base no número e no arranjo das camadas tetraédricas (de sílica) e octraédricas (de alumina), contidas nas unidades cristalográficas, as argilas silicatadas podem ser classificadas em quatro diferentes grupos: (i) minerais do tipo 1:1; (ii) minerais do tipo 2:1, expansíveis; (iii) inexpansíveis e (iv) minerais do tipo 2:2 (Brady, 1979).

A fração mineral ou inorgânica representa a maior parte da fase sólida dos solos bem drenados, os quais não apresentam acúmulo anormal de matéria orgânica.

Os minerais do solo costumam ser separados em minerais primários e secundários. Os primários são aqueles que existem normalmente em rochas ígneas e podem persistir no solo. Os minerais secundários são formados pela decomposição dos minerais primários por processos químicos e recombinação em novos minerais. Os minerais secundários podem formar-se no próprio solo ou, o que é mais comum, durante processos gerais de intemperismo e translocação de elementos químicos, dando origem às rochas sedimentares.

Kampf \& Klamt (1978), comentam que a freqüência de distribuição dos minerais nos solos varia com a intensidade dos fatores de formação. 0 material de origem fornece 0 grupo inicial de minerais que, por sua vez, influi na mineralogia do solo como decorrência de sua susceptibilidade ao intemperismo.

Gunn (1974), estudando uma catena de solos desenvolvidos a partir de basaltos, evidenciou uma mudança mineralógica da fração argila, a qual passou de caulinita para montmorilonita no sentido de solos mais jovens.

A presença dominante de caulinita, quantidades secundárias de materiais amorfos, vermiculita, mica, goetita, hematita e gibsita em Terra Roxa Estruturada de regiões tropicais, submetida a intenso intemperismo, foram constatadas por Curi (1975) e GaIhego \& Espíndola (1979).

As condições de clima tropical úmido são muito favoráveis ao acentuado intemperismo, 0 que se deve a alta temperatura associada com umidade, e uma constante remoção de elementos químicos pela lixiviação promovida pela água que percola o perfil, situação predominante nas regiões tropicais e subtropicais, cujos solos contêm em sua fração argila uma predominância de ferro, alumínio e silício.

Solos em cujas texturas predominam areias, contêm, em geral, minerais primários mais resistentes com destaque para 0 quartzo $\left(\mathrm{SiO}_{2}\right)$, razão pela qual é o mineral mais abundante na maioria dos solos.

\section{Capacidade de troca catiônica (CTC) dos solos}

Nos solos, cujas trocas químicas são regidas por cargas positivas e negativas, ocorrem muitos fenômenos na fração argila, sendo um deles 0 da troca catiônica. 
Na maioria dos solos da crosta terrestre predominam cargas negativas, denominados eletronegativas, sendo rara no Brasil a ocorrência de solos com cargas eletropositivas (Vieira, 1975).

As cargas negativas dispostas na superfície dos minerais de argila e da matéria orgânica são capazes de adsorver íons com cargas opostas (cátions), como $\mathrm{Ca}^{2+}, \mathrm{Mg}^{2+}, \mathrm{K}^{+}, \mathrm{H}^{+}$, etc. Estes cátions adsorvidos podem ser substituídos, isto é trocados uns pelos outros. A esse fenômeno dá-se o nome de troca de cátions, e ao conjunto das cargas negativas dá-se o nome de capacidade de troca de cátions (Resende et al., 1995).

A propriedade de troca de íons existe em inúmeras substâncias naturais e artificiais. Trocadores de íons são materiais sólidos que apresentam um excesso de carga elétrica, carga esta balanceada por íons trocáveis e que ficam adsorvidos na superfície da interface sólido-liquido em níveis microscópicos dos solos (Raij, 1983).

Além dos minerais de argila que conferem cargas aos solos, outro elemento de suma importância na dinâmica de adsorção dos cátions é a matéria orgânica. Em solos tropicais e subtropicais altamente intemperizados, a matéria orgânica é de grande importância como fonte de nutrientes para as plantas, além da retenção de cátions e da complexação de elementos tóxicos e de micronutrientes, à estabilidade da estrutura, à infiltração e retenção de água, à aeração, etc. (Bayer \& Mielniczuk, 1997).

Diferente dos minerais de argila do tipo 2:1, a matéria orgânica dos solos não possui um valor fixo de CTC. Isso ocorre não somente porque a acidez das substâncias húmicas varia diferentemente dos minerais mencionados (Celi et al., 1997), mas também porque a CTC da matéria orgânica aumenta com a elevação do pH em função da ionização de grupos acídicos (Velloso et al., 1982).

Em comparação com alguns minerais de argila que apresentam CTC baixa (caulinita: $3-5 \mathrm{cmol}_{\mathrm{c}} \mathrm{Kg}^{-1}$; montmorilonita: 80-150 $\mathrm{cmol}_{\mathrm{c}} \mathrm{Kg}^{-1}$ ), as substâncias húmicas apresentam CTC que varia de 400 a $1000 \mathrm{cmol}_{\mathrm{c}} \mathrm{Kg}^{-1}$, o que explica a sua significativa contribuição na CTC dos solos (Theng et al., 1989).

\section{CARACTERIZAÇÃO DA ÁREA DE ESTUDO}

A área de estudo localiza-se próximo a cidade Maringá (Figura 1), considerada pólo regional agrícola e vem sendo utilizada com 0 cultivo de soja no verão e trigo no inverno. 0 clima, de acordo com a carta climática do Paraná (lapar, 1978), tendo por base a classificação de Köeppen, é Cfa, ou seja, subtropical úmido mesotérmico, verões quentes, com tendência de concentração de chuvas nos meses de verão, cuja precipitação média anual é de $1200 \mathrm{~mm}$. Situada no Terceiro Planalto Paranaense, a área envolve 0 Grupo Cauiá em domínios da Formação GoioErê (Fernandes \& Coimbra, 2000) e apresenta contato transicional com a Formação Serra Geral (basaltos). Ainda segundo os autores, a Formação Goio-Erê é constituída por arenitos quartzosos, marrom-avermelhados e cinza arroxeados, finos a muito finos, mineralogicamente maturos e texturalmente submaturos. Nas partes mais planas predominam materiais retrabalhados das formações Goio-Erê e Serra Geral, originando solos de textura mista entre arenosos e argilosos. Na medida em que o relevo fica mais acidentado, predominam solos de textura argilosa, oriundos da Formação Serra Geral, cujas rochas afloram em algumas drenagens. Gimenez et al. (1983) descrevem que na região a paisagem é representada pela ocorrência de relevo de colinas amplas de pequena amplitude, com perfil retilíneo e convexo contínuo e topos extensos planos. As rampas são longas e pouco declivosas enquanto os gradientes mais acentuados ocorrem apenas próximos aos canais de drenagem.

\section{MATERIAIS E MÉTODOS}

\section{Gamaespectrometria}

Utilizou-se 0 gamaespectrômetro portátil GS-512 fabricado pela Geofyzika (República Tcheca) e comercializado pela Scintrex (Canadá), projetado para operar com 512 canais num intervalo de 0,1 a $3 \mathrm{Mev}$, pertencente ao Laboratório de Pesquisas em Geofísica Aplicada - LPGA/UFPR, para a coleta dos dados. 0 GS-512 consiste de uma sonda ( $45 \mathrm{~cm}$ de comprimento; $12,5 \mathrm{~cm}$ de diâmetro e pesa $4,6 \mathrm{~kg}$ ), a qual encerra um cristal de $76 \times 76 \mathrm{~mm}$ de $\mathrm{Nal}(\mathrm{TI})$, além de um circuito de detecção e uma fonte radioativa $\left({ }^{137} \mathrm{Cs}\right)$ de referência. Um outro módulo $(23,5 \times 23,0 \times 9,0$ cm) armazena e processa os dados medidos. Os dados aqui apresentados estão em ppm de K, eU e eTh, mas também em Bq Kg${ }^{-1}$, no sentido de facilitar comparações com a literatura internacional. Para tanto, as relações adotadas foram as seguintes: $1 \%$ de $\mathrm{K}$ equivale a $310 \mathrm{~Bq} \mathrm{Kg}{ }^{-1}$ e 1 ppm de $\mathrm{U}$ e de Th equivalem a 12,3 e $4,07 \mathrm{~Bq} \mathrm{Kg}^{-1}$, respectivamente (Sroor et al., 2001).

A maioria dos elementos pertencentes as séries radioativas naturais, apresentam número atômico entre $Z=81 \mathrm{e} \mathrm{Z}=92$ (Arya, 1966). Os elementos de ocorrência natural que produzem raios gama de suficiente intensidade e energia para serem medidos por gamaespectrômetros são: 0 potássio, 0 urânio e 0 tório. 0 potássio é identificado e quantificado pelo instrumento através da absorção de uma energia de 1,46 Mev, correspondente ao único isótopo natural $\left({ }^{40} \mathrm{~K}\right), 0$ qual representa $0,012 \%$ do $\mathrm{K}$ total (os outros isótopos, ${ }^{39} \mathrm{~K}$ e ${ }^{41} \mathrm{~K}$, não são radioativos e representam, 


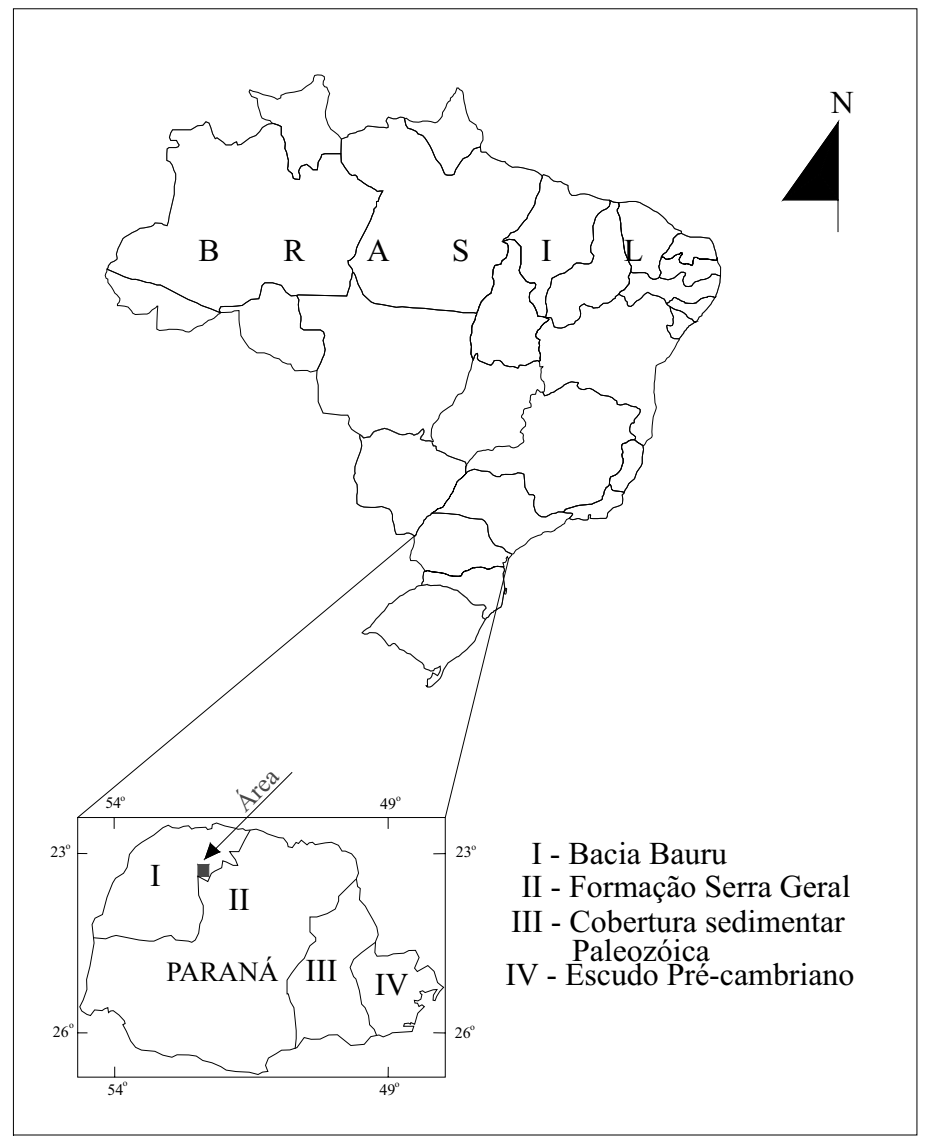

Figura 1 - Localização da área e os compartimentos geológicos do estado do Paraná.

respectivamente, 93,26\% e 6,73\% do K total). Os isótopos naturais da série do urânio constituem uma mistura, principalmente de ${ }^{238} \mathrm{U}(99,3 \%) \mathrm{e}^{235} \mathrm{U}(0,7 \%)$, representativa de complexas cadeias de decaimento, as quais terminam em isótopos estáveis de ${ }^{206} \mathrm{~Pb}$ e ${ }^{207} \mathrm{~Pb}$, respectivamente. 0 urânio é detectado pela energia de 1,76 Mev, correspondente à absorção do ${ }^{214} \mathrm{Bi}$ da série do ${ }^{238} \mathrm{U}$, utilizada para identificar e quantificar o urânio natural. 0 tório natural é essencialmente composto pelo isótopo ${ }^{232}$ Th e seus produtos de decaimento, representando $100 \%$ do Th total. É identificado pelo pico do ${ }^{208} \mathrm{TI}$, correspondente a uma energia de absorção de 2,62 Mev. Portanto as concentrações de urânio e tório são determinadas indiretamente pelos gamaespectrômetros, razão pela qual são denominadas equivalente de urânio (eU) e equivalente de tório (eTh), respectivamente.

\section{Calibração do gamaespectrômetro}

0 instrumento foi calibrado no Instituto de Radioproteção e Dosimetria (IRD) da Comissão Nacional de Energia Nuclear (CNEN), em 23 de fevereiro de 2003, segundo procedimentos descritos em Ferreira et al. (2003). 0 sistema de calibração (Barretto et al., 1986) é constituído por oito blocos cilíndricos (pads) de concreto (diâmetro de 3,0 metros; espessura de 0,5 metro; densidade de $2,1 \mathrm{~g} / \mathrm{cm}^{3}$; volume de $3,53 \mathrm{~m}^{3}$; peso de 7,41 toneladas), dispostos nos jardins do IRD/CNEN (0,5 metro acima do nível do mar) ao longo de um círculo com 20 metros de diâmetro, portando sujeitos a variações climáticas e do radônio atmosférico, 0 que pode influenciar a quantificação dos teores em função do tempo, embora durante a inspeção visual não tenham sido observadas fraturas nem alterações intempéricas significativas em suas superfícies. Em seu centro, um reservatório de 4,0 metros de diâmetro e 0,7 metro de espessura preenchido por água, foi utilizado para monitorar a radiação cósmica, o radônio e os ruídos instrumentais.

As fontes são constituídas de concreto comum, nas quais foram utilizadas uma mistura de cimento, brita de granito e areia na proporção de 1:2:3, respectivamente. A granulometria do agregado foi menor que 1 centímetro para facilitar a mistura e a 
homogeneização com material radioativo. Todas as fontes, exceto 0 background (BKG), foram contaminadas com material radioativo em diversas proporções e combinações (Barretto et al., 1986). A Tabela 1 mostra as concentrações de K (\%), U (ppm) e Th (ppm) das fontes, consideradas em equilíbrio secular, derivadas de um grande número (1.266 determinações válidas dentre 2.180) de análises químicas e por ativação neutrônica, conforme Barretto et al. (1986), indicando as incertezas em termos de um erro padrão da média (Ribeiro et al., 2005), além do número de determinações. As concentrações também foram monitoradas por gamaespectrômetros durante a construção das fontes, do que resultaram teores de $\mathrm{K}$, U e Th recomendados por Barretto et al. (1986). As diferenças em relação a Tabela 1 se concentram, em relação ao urânio, no BKG $(0,50 \pm 0.01$ ppm), e nos pads U1 e UTh2 $(56,89 \pm 1,15$ e $38,95 \pm 0,81$ ppm, respectivamente). Já em relação ao tório, 0 teor recomendado para 0 pad U2 é de 45, $57 \pm 0,57$ ppm. Tais diferenças foram sugeridas por Barretto et al. (1986) para compensar os efeitos de possíveis desequilíbrios na série do urânio, embora Ribeiro et al. (2005) comentem que não existe clareza, sobretudo para os dados radiométricos, para justificar cabalmente a hipótese de desequilíbrio e as conseqüentes correções propostas. Tais autores também chamam a atenção para 0 fato de que a maioria das determinações radiométricas situam-se num intervalo de dois desvios padrão em torno dos valores obtidos nas análises químicas e por ativação neutrônica.

As leituras de calibração foram tomadas nos pads K1, U1, Th1, BKG e sobre lâmina d'água, com tempos de 10 minutos. A radiação cósmica (maior que $3.000 \mathrm{KeV}$ ) foi automaticamente monitorada pelo GS-512. Como sabido, as medidas das contagens nos pads de calibração, nas janelas de $\mathrm{K}\left({ }^{40} \mathrm{~K}-1,46 \mathrm{Mev}\right), \mathrm{U}$ $\left({ }^{214} \mathrm{Bi}-1,76 \mathrm{Mev}\right)$ e Th $\left({ }^{208} \mathrm{Tl}-2,62 \mathrm{Mev}\right)$ guardam relação linear com as concentrações das fontes. Através da subtração das contagens e das concentrações do BKG, deriva um conjunto de três equações com três incógnitas para cada uma das janelas mencionadas. De acordo com o manual do instrumento (Geofyzika, 1998), uma matriz de concentração $3 \times 3$ [Q], calculada pelos parâmetros representativos dos teores das fontes K1, U1 e Th1 e de um fator geométrico (que para um pad cilíndrico é dado por $G=1-h / r$, onde $h$, em metros, é a altura do detector em relação à superfície da fonte e r é o raio do pad. Como no processo de calibração o sensor foi disposto diretamente sobre a superfície das fontes, decorre $G=1$ ), está relacionada com uma matriz equivalente de contagens [n], calculada pelas medidas nos pads citados, além do BKG e sobre lâmina d'água, e com uma matriz de calibração [C] composta por algumas constantes de calibração, do que resulta a seguinte equação matricial:

$$
[\mathrm{Q}]=[\mathrm{C}] \times[\mathrm{n}] \text {, ou }[\mathrm{C}]=[\mathrm{Q}] /[\mathrm{n}]
$$

Desta forma, uma vez 0 instrumento calibrado, foram tomadas leituras em todos os oito pads, com duração de 3 minutos, considerada satisfatória para trabalhos rotineiros de campo. As Tabelas 2, 3 e 4 mostram as concentrações de K(\%), eU (ppm) e eTh (ppm), respectivamente, subtraídas do BKG, de acordo com Barretto et al. (1986), modificadas por Ribeiro et al. (2005), Ferreira et al. (2003) e Ribeiro et al. (2005).

A comparação das Tabelas 2 e 4 mostra que as determinações do potássio e do tório, calculadas por Ferreira et al. (2003), estão em conformidade com os dados de Barretto et al. (1986), modificados por Ribeiro et al. (2005). Em relação aos teores de urânio do pad U1 (Tabela 3), foram encontradas diferenças fora do intervalo definido por um desvio padrão em torno dos valores médios das concentrações, também assinaladas por Ribeiro et al. (2005). Verificou-se ainda contrastes não significativos nos pads U2 e UTh2 (Tabela 3). Por outro lado, a comparação entre os resultados do potássio determinados por Ferreira et al. (2003) e Ribeiro et al. (2005) mostrou-se satisfatória, à exceção de pequena modificação no pad K2 (Tabela 2). Já para 0 urânio verificase uma diferença em torno de 1 ppm no pad U1, podendo-se considerar desprezíveis as variações nos pads U2 e UTh2 (Tabela 3). Em relação ao tório, foram os seguintes os valores encontrados por Ferreira et al. (2003) versus os índices mínimos calculados por Ribeiro et al. (2005) para os pads K1, K2, Th1, UTh1 e UTh2, respectivamente: $15,93 \times 16,5 ; 28,81 \times 29,2$; $248,63 \times 261 ; 68,81 \times 71 ; 162,11 \times 167,6$ (Tabela 4).

Os dados gamaespectrométricos (3 minutos por leitura), foram tomados conforme a Figura 2, bem como em solos sob floresta nativa (sem contaminação por atividade antrópica) e em amostras de adubos e gesso. Nos solos, noventa por cento dos raios gama são emanados pela camada superficial, cuja profundidade máxima é de $45 \mathrm{~cm}$ (Wilford et al., 1997). Nos pontos indicados na Figura 2, sobrepostos ao mapa de solos, foram também coletados dados de resistividade aparente, de susceptibilidade magnética e de teores de argila e matéria orgânica em duas profundidades $(0-20$ e 20-40 cm).

\section{Resistividade}

Considere-se um cubo eletricamente uniforme com aresta de comprimento L, através do qual circula uma corrente elétrica I, e que uma substância que o preenche provoque uma diferença de potencial $\Delta V$ entre faces opostas. A resistência $R$ é diretamente proporcional ao comprimento $L$ e inversamente proporci- 
Tabela 1 - Concentrações dos radioelementos nos pads do IRD/CNEN determinadas por análises químicas e ativação neutrônica, de acordo com Barretto et al. (1986). As incertezas correspondem às estimativas de desvios padrão e o número de determinações é indicado entre parênteses.

\begin{tabular}{|c|c|c|c|}
\hline Pads & Concentração de K (\%) & Concentração de U (ppm) & Concentração de Th (ppm) \\
\hline BKG & $0,08 \pm 0,01(95)$ & $0,82 \pm 0,01(70)$ & $1,75 \pm 0,12(28)$ \\
\hline K1 & $6,74 \pm 0,06(25)$ & $2,00 \pm 0,07(62)$ & $20,90 \pm 0,81(23)$ \\
\hline K2 & $4,43 \pm 0,08(64)$ & $2,97 \pm 0,06(79)$ & $29,72 \pm 1,39(22)$ \\
\hline U1 & $3,47 \pm 0,04(39)$ & $69,92 \pm 0,67(85)$ & $50,13 \pm 0,99(44)$ \\
\hline U2 & $3,43 \pm 0,08(39)$ & $19,45 \pm 0,14(58)$ & $53,06 \pm 1,68(34)$ \\
\hline Th1 & $3,54 \pm 0,07(52)$ & $11,63 \pm 0,15(37)$ & $255,97 \pm 5,25(47)$ \\
\hline UTh1 & $3,64 \pm 0,03(64)$ & $12,10 \pm 0,24(78)$ & $71,59 \pm 1,76(48)$ \\
\hline UTh2 & $3,65 \pm 0,03(27)$ & $44,47 \pm 0,63(91)$ & $152,39 \pm 4,76(55)$ \\
\hline
\end{tabular}

Tabela 2 - Comparação entre as concentrações de potássio (K, \%) nos pads do IRD/CNEN determinadas por análises químicas e ativação neutrônica por Barretto et al. (1986), modificadas por Ribeiro et al. (2005) ${ }^{1}$, e calculadas por Ferreira et al. (2003) ${ }^{2}$ e Ribeiro et al. (2005) ${ }^{3}$.

\begin{tabular}{|c|c|c|c|}
\hline Pads & Concentração de K (\%) ${ }^{1}$ & Concentração de K (\%) ${ }^{2}$ & Concentração de $\mathrm{K}(\%)^{3}$ \\
\hline K1 & $6,66 \pm 0,32$ & 6,53 & $6,50 \pm 0,16$ \\
\hline K2 & $4,35 \pm 0,65$ & 4,89 & $4,63 \pm 0,13$ \\
\hline U1 & $3,39 \pm 0,27$ & 3,35 & $3,40 \pm 0,13$ \\
\hline U2 & $3,35 \pm 0,51$ & 3,41 & $3,42 \pm 0,13$ \\
\hline Th1 & $3,46 \pm 0,52$ & 3,62 & $3,51 \pm 0,22$ \\
\hline UTh1 & $3,56 \pm 0,26$ & 3,49 & $3,55 \pm 0,11$ \\
\hline UTh2 & $3,57 \pm 0,19$ & 3,47 & $3,43 \pm 0,19$ \\
\hline
\end{tabular}

Tabela 3 - Comparação entre as concentrações de urânio (U, ppm) nos pads do IRD/CNEN determinadas por análises químicas e ativação neutrônica por Barretto et al. (1986), modificadas por Ribeiro et al. (2005) ${ }^{1}$ e calculadas por Ferreira et al. (2003) ${ }^{2}$ e Ribeiro et al. (2005) ${ }^{3}$.

\begin{tabular}{|c|c|c|c|}
\hline Pads & Concentração de U (ppm) ${ }^{1}$ & Concentração de eU (ppm) $^{2}$ & Concentração de eU (ppm) $^{3}$ \\
\hline K1 & $1,18 \pm 0,56$ & 1,70 & $1,69 \pm 0,45$ \\
\hline K2 & $2,15 \pm 0,54$ & 1,89 & $2,11 \pm 0,55$ \\
\hline U1 & $69,10 \pm 6,20$ & 55,89 & $57,90 \pm 3,20$ \\
\hline U2 & $18,63 \pm 1,10$ & 20,04 & $21,10 \pm 1,30$ \\
\hline Th1 & $10,81 \pm 0,91$ & 10,82 & $11,4 \pm 1,60$ \\
\hline UTh1 & $11,28 \pm 2,10$ & 10,91 & $10,67 \pm 0,94$ \\
\hline UTh2 & $43,65 \pm 6,00$ & 37,44 & $39,90 \pm 2,10$ \\
\hline
\end{tabular}

onal à área transversal A das faces. A constante de proporcionalidade $\rho$ é definida como a resistividade verdadeira da substância. Então $R=\rho^{*} L / A$ e, pela Lei de $0 \mathrm{hm}, \mathrm{R}=\Delta \mathrm{V} / \mathrm{l}$, ou alternativamente, $\rho=\mathrm{E} / \mathrm{J}$, onde E expressa o campo elétrico (volts/m) e J é densidade de corrente (ampère/ $/ \mathrm{m}^{2}$ ), conforme Reynolds (2003). Assim, segundo Koefoed (1979), a resistividade elétrica de uma substância pode ser definida como a resistência à passagem de corrente, sendo expressa em unidade de resistência multiplicada 
Tabela 4 - Comparação entre as concentrações de tório (Th, ppm) nos pads do IRD/CNEN determinadas por análises químicas e ativação neutrônica por Barretto et al. (1986), modificadas por Ribeiro et al. $(2005)^{1}$ e calculadas por Ferreira et al. $(2003)^{2}$ e Ribeiro et al. (2005) ${ }^{3}$.

\begin{tabular}{|c|c|c|c|}
\hline Pads & ${\text { Concentração de Th }(\mathrm{ppm})^{1}}^{1}$ & Concentração de eTh (ppm) $^{2}$ & Concentração de eTh (ppm) $^{3}$ \\
\hline K1 & $19,15 \pm 4,00$ & 15,93 & $17,60 \pm 1,10$ \\
\hline K2 & $27,97 \pm 6,50$ & 28,81 & $30,80 \pm 1,60$ \\
\hline U1 & $48,30 \pm 6,60$ & 45,62 & $45,10 \pm 2,10$ \\
\hline U2 & $51,31 \pm 9,80$ & 44,14 & $46,00 \pm 2,10$ \\
\hline Th1 & $254,22 \pm 36,00$ & 248,63 & $271,00 \pm 10,00$ \\
\hline UTh1 & $69,84 \pm 12,00$ & 68,81 & $74,10 \pm 3,10$ \\
\hline UTh2 & $150,62 \pm 35,00$ & 162,11 & $174,20 \pm 6,60$ \\
\hline
\end{tabular}

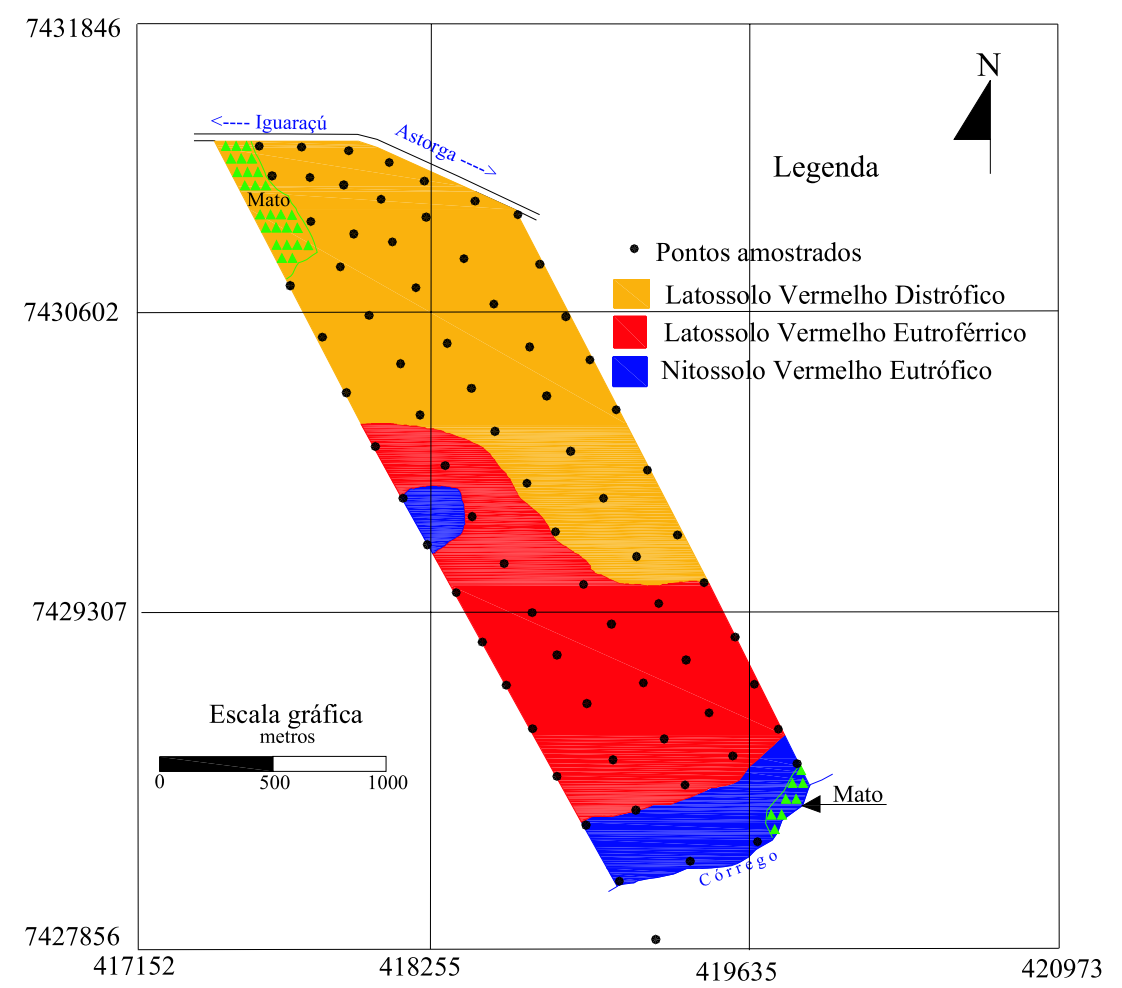

Figura 2 - Mapa de solos indicando os pontos de amostragem de solos, gamaespectrométricos, resistivimétricos e a área livre de atividade agrícola (floresta nativa).

por unidade de comprimento (Ohm.m).

A resistividade é uma propriedade física de cada substância, havendo sido medida e tabelada para vários materiais. No entanto as rochas e principalmente os solos, são meios de grandes variações laterais e verticais de propriedades físicas e químicas, as quais se refletem nas determinações da resistividade. As rochas e os solos são bastante resistivos, mas a presença de substâncias metálicas, argilas e sais dissolvidos, podem favorecer a passagem de corrente elétrica. Este fato levou à idealização desse método, inicialmente para prospecção de minerais metálicos, mas ao longo do século XX suas aplicações se diversificaram, sobretudo, aquelas vinculadas com a prospecção 
de água subterrânea, porque a presença de fluidos em poros e/ou fraturas, normalmente contendo sais dissolvidos, determina uma redução da resistividade.

Apesar dos solos serem resistivos, sua resistividade depende, no mínimo, dos seguintes fatores: grau de saturação, resistividade do líquido nos poros, porosidade, tamanho e forma das partículas sólidas, espessura e composição da camada catiônica dos argilominerais. Curiosamente, a dependência da resistividade em relação a um grande número de fatores pode ser uma vantagem no que diz respeito às ciências dos solos. Neste sentido, por exemplo, considerando um mesmo teor de umidade, solos com maiores concentrações de argila facilitam a passagem da corrente elétrica, ao contrário dos arenosos, onde a resistividade esperada é maior.

Corwin \& Rhoades (1984) salientam que a medição indireta da salinidade do solo, por meio da condutividade elétrica da porção que vai até 90 centímetros, é muito importante, uma vez que é nesta profundidade que se concentra a atividade das raízes das plantas.

Shainberg et al. (1980) e Nadler \& Frenkel (1980), trabaIhando com a condutividade elétrica ao invés da resistividade, mostraram que existe uma relação diretamente proporcional entre a condutividade de solos areno-siltosos saturados e a condutividade intersticial salina.

Autores como McBride et al. (1990), consideram que as medidas de condutividade elétrica, e, conseqüentemente, de resistividade, podem fornecer uma visão integrada dos parâmetros relacionados com a produtividade agrícola.

No método elétrico uma corrente contínua I é injetada no terreno através de dois eletrodos (A e B), e a diferença de potencial $\Delta V$ é medida por meio de outros dois eletrodos ( $\mathrm{M}$ e $\mathrm{N}$ ), todos fixados em linha reta na superfície do terreno. A função resistividade aparente $\left(\rho_{a}\right)$ é dada pela seguinte expressão: $\rho_{a}=$ $\mathrm{K}^{*} \Delta \mathrm{V} / \mathrm{l} . \mathrm{O}$ fator $\mathrm{K}$ que multiplica $\Delta \mathrm{V} / \mathrm{l}$ é puramente geométrico $\mathrm{e}$ depende apenas da disposição dos eletrodos A, B, M e N. A resistividade aparente $\left(\rho_{a}\right)$ não é um parâmetro físico do meio, mas um efeito integrado sobre um segmento do semi-espaço, para a qual contribuem os valores da resistividade em cada ponto; a geometria elétrica do terreno e a disposição geométrica dos eletrodos. 0 solo possui um potencial elétrico natural, denominado potencial espontâneo, 0 qual deverá ser deduzido da medição obtida com os eletrodos M e N. Conhecendo-se a corrente que percorre o subsolo, a disposiçãa dos eletrodos e a diferença de potencial, pode-se calcular o valor da resistividade aparente em cada posição do arranjo, como referido.

A resistividade aparente foi determinada sobre os mesmos pontos indicados na Figura 2. 0 equipamento utilizado foi o resistivímetro ER-300, cedido na forma de empréstimo pelo Laboratório de Geofísica Aplicada (LGA), do Instituto de Geociências da Universidade de Brasília (IG-UnB). 0 espaçamento (a) utilizado entre os eletrodos de corrente e de potencial foi de $1 \mathrm{~m}$, segundo 0 arranjo Wenner $(K=2 \pi a)$, objetivando adquirir valores de resistividade aparente até aproximadamente $50 \mathrm{~cm}$ de profundidade (Nascimento et al., 2004).

\section{Susceptibilidade magnética}

De acordo com Sheriff (1999), a susceptibilidade magnética é uma medida do grau segundo o qual uma determinada substância pode ser magnetizada e representa a razão $k$ ou $k$ ' entre a magnetização (momento magnético por unidade de volume, ou uma medida do efeito causado no campo magnético por uma força magnetizante $\mathrm{H}$ ), M ou I, e a força magnetizante $\mathrm{H}$ (uma medida da influência de um magneto no espaço circundante), ou seja, $\mathrm{k}=\mathrm{M} / \mathrm{H}$ (no sistema SI) ou k' = I/H (no sistema cgs). A susceptibilidade magnética é uma propriedade física intrínseca das rochas e solos, constituindo uma grandeza adimensional cujas magnitudes são distintas nos dois sistemas, ou seja, $\mathrm{k}=4 \pi \mathrm{k}$.

Foram coletadas amostras de solos em 77 pontos (Figura 2), para quantificar a susceptibilidade magnética $(\mathrm{k})$ nas profundidades de $0-20 \mathrm{~cm}$ e $20-40 \mathrm{~cm}$, totalizando 154 amostras. Em laboratório foram procedidas as determinações de $\mathrm{k}$ diretamente nas amostras, através do indicador de susceptibilidade (kappameter) KT-5, fabricado pela Geofyzika (República Tcheca), comercializado pela Scintrex (Canadá) e pertencente ao LPGA/UFPR. 0 instrumento tem uma acurácia de $1 \times 10^{-5}$ unidade $\mathrm{SI}$, os intervalos das medidas são de 9,99, 99.9 e $999 \times 10^{-3} \mathrm{SI}$, opera com uma freqüência de $10 \mathrm{kHz}$ e sua memória é suficiente para armazenar apenas 12 leituras.

\section{Difratometria de Raios X}

As amostras de solos in natura foram quarteadas, pulverizadas e homogeneizadas com água em moinho excêntrico, para preparação das lâminas. A medição dos parâmetros cristalinos em algumas amostras foi realizada através da difração de raios $X$. 0 equipamento utilizado foi o difratômetro da marca Philips, modelo PW 1830, do Laboratório de Análise de Minerais e Rochas (LAMIR), Departamento de Geologia da UFPR.

Para a interpretação dos dados utilizou-se 0 software $X$ Pert HighScore, que possui um banco de dados de todos os minerais conhecidos, onde é possivivel, por comparação dos valores dos picos em Angstrom, identificar os minerais. 
Para a determinação dos minerais utilizou-se diferentes tratamentos, objetivando a comparação dos difratogramas. Cada um dos tratamentos ocasiona modificações nas estruturas cristalinas, são eles: análise com lâmina do material lavado, precipitado e seco; análise com lâmina do material tratado com etilenoglicol e análise com lâmina do material aquecido (2 horas) em mufla a $550^{\circ} \mathrm{C}$

\section{Quantificação dos teores de argila e matéria orgânica}

Foram coletadas amostras de solos em 77 pontos (Figura 2), para quantificar os teores de argila e matéria orgânica nas profundidades de $0-20 \mathrm{~cm}$ e $20-40 \mathrm{~cm}$, totalizando 154 amostras. Em laboratório procedeu-se as determinações dos teores de argila e matéria orgânica, cujos procedimentos podem ser vistos em Tedesco et al. (1995). A maior profundidade das coletas (20 - $40 \mathrm{~cm})$ guarda correspondência aos níveis mais inferiores de emanação dos raios gama. Os laudos foram emitidos pelo Laboratório de Análise de Solos da Universidade do Estado de Santa Catarina, Centro de Ciências Agroveterinárias de LagesSC, o qual integra a Rede Oficial de Laboratórios dos Estados de Santa Catarina e Rio Grande do Sul, cujo controle de qualidade é sistematicamente realizado pela Empresa Brasileira de Pesquisas Agropecuárias (Embrapa, Passo Fundo-RS).

\section{RESULTADOS E DISCUSSÃO}

Na área investigada foram identificados e mapeados 3 tipos de solos (Figura 2), os quais foram enquadrados na nova classificação vigente a partir de 1999, cujas correlações com as antigas nomenclaturas podem ser vistas em Prado (2001). São eles: (i) Nitossolo Vermelho Eutrófico de textura argilosa (antiga Terra Roxa Estruturada), derivado de rochas basálticas, cuja inserção espacial se dá mais próxima aos canais de drenagens, com relevo mais acidentado; (ii) Latossolo Vermelho Eutroférrico (antigo Latossolo Roxo), é um solo mais velho comparativamente ao anterior, de textura argilosa, mais profundo, também originado de rochas basálticas e situado em relevo suave ondulado a praticamente plano e (iii) Latassolo Vermelho Distrófico (antigo Latossolo Vermelho), oriundo do retrabalhamento das Formações Serra Geral e Goio-Erê, cujo teor de argila está entre 16 e 35\%, considerado pedologicamente de textura média e espacialmente distribuído em relevo praticamente plano. A Figura 3 exibe o modelo digital de elevação (MDE) da área. As figuras 4, 5 e 6 representam, respectivamente, as distribuições espaciais do urânio, do tório e do potássio na área de estudo.

Para o plantio de soja e trigo na área, a qual envolve 340 hec- tares, são utilizados aproximadamente 100 toneladas de fertilizantes ao ano para as duas culturas, objetivando altas produtividades. 0 volume de fertilizantes é a principal variável na composição dos custos de produção, o qual pode oscilar em função do preço do produto em vigor na época do plantio.

As estatísticas descritivas gerais dos dados gamaespectrométricos, de resistividade aparente e dos teores de argila (0-20 e 20-40 cm) são apresentados na Tabela 5. Entretanto, em virtude de diferenças na textura dos solos, essencialmente refletida pelos teores de argila e de susceptibilidade magnética (0-20 e 20$40 \mathrm{~cm}$ ), é de se esperar variações dos parâmetros analisados, pelo que os dados foram reorganizados, separando um conjunto representativo dos solos argilosos, cujos teores de argila são maiores do que $35 \%$ e outro característico do solo areno-argiloso, com percentagem de argila na faixa de 16 a $35 \%$ conforme as Tabelas 6,7 e 8 .

\section{Correlações entre radiação gama dos solos, adubos, gesso e rochas}

Os valores médios dos radionuclídeos para os 77 pontos foram de $54,75 \mathrm{~Bq} \mathrm{Kg}^{-1}$ (1766 ppm) de K, 10,22 $\mathrm{Bq} \mathrm{Kg}^{-1}$ (0,83 ppm) de eU e 7,25 Bq Kg${ }^{-1}$ (1,78 ppm) de eTh (Tabela 5). Souza (1998), encontrou valores de $86,1 \mathrm{~Bq} \mathrm{Kg}^{-1}$ (7 ppm) de $\mathrm{U}$ em solos argilosos no município de Araras-SP, enquanto Kumru \& Bakaç (2003) obtiveram índices médios de $135 \mathrm{~Bq} \mathrm{Kg}^{-1}$ (11 ppm) de U e 17,05 $\mathrm{Bq} \mathrm{Kg}^{-1}$ (4,19 ppm) de Th. Kannan et al. (2002) pesquisando radionuclídeos em solos da Índia, encontraram valores de U que vão desde 16 até $359,65 \mathrm{~Bq} \mathrm{Kg}^{-1}$ (1,30 a 29,24 ppm).

Levando-se em consideração os solos analisados e suas respectivas texturas, os argilosos (Latossolo Vermelho Eutroférrico e o Nitossolo Vermelho Eutrófico), apresentaram valor médio de urânio de $14,9 \mathrm{Bg} \mathrm{Kg}^{-1}$ (1,2ppm), enquanto 0 areno-argiloso (Latossolo Vermelho Distrófico) revelou concentração média de 7,03 Bq Kg-1 (0,57 ppm), de acordo com as Tabelas 7 e 8. 0 teor de urânio é duas vezes maior nos solos argilosos, cujo coeficiente de variação foi de 19,92\%, representando menor dispersão dos dados, quando comparado com os $48,4 \%$ de toda a área. 0 teor médio de potássio no solo areno-argiloso foi de $57,28 \mathrm{~Bq}$ $\mathrm{Kg}^{-1}$ (1847,7 ppm), ligeiramente maior do que nos solos argilosos, cuja média foi de $51 \mathrm{~Bq} \mathrm{Kg}^{-1}$ (1645,1ppm). Já 0 tório indicou concentração média de 9,03 Bq/Kg (2,2ppm) no solo areno-argiloso, portanto maior do que os $4,61 \mathrm{~Bq} \mathrm{Kg}^{-1}(1,13$ ppm) dos solos argilosos.

Para as áreas sem atividade agrícola, cujos solos se encontram sob vegetação nativa, fragmentos de florestas consideradas 


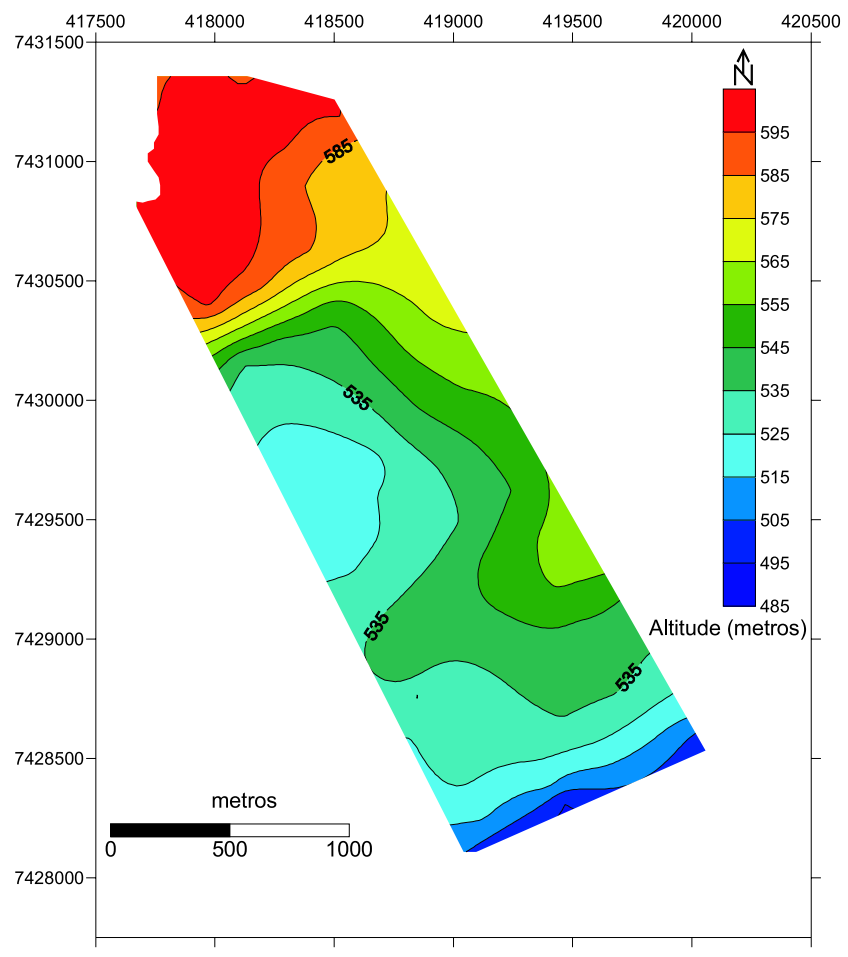

Figura 3 - Modelo digital de elevação (MDE).

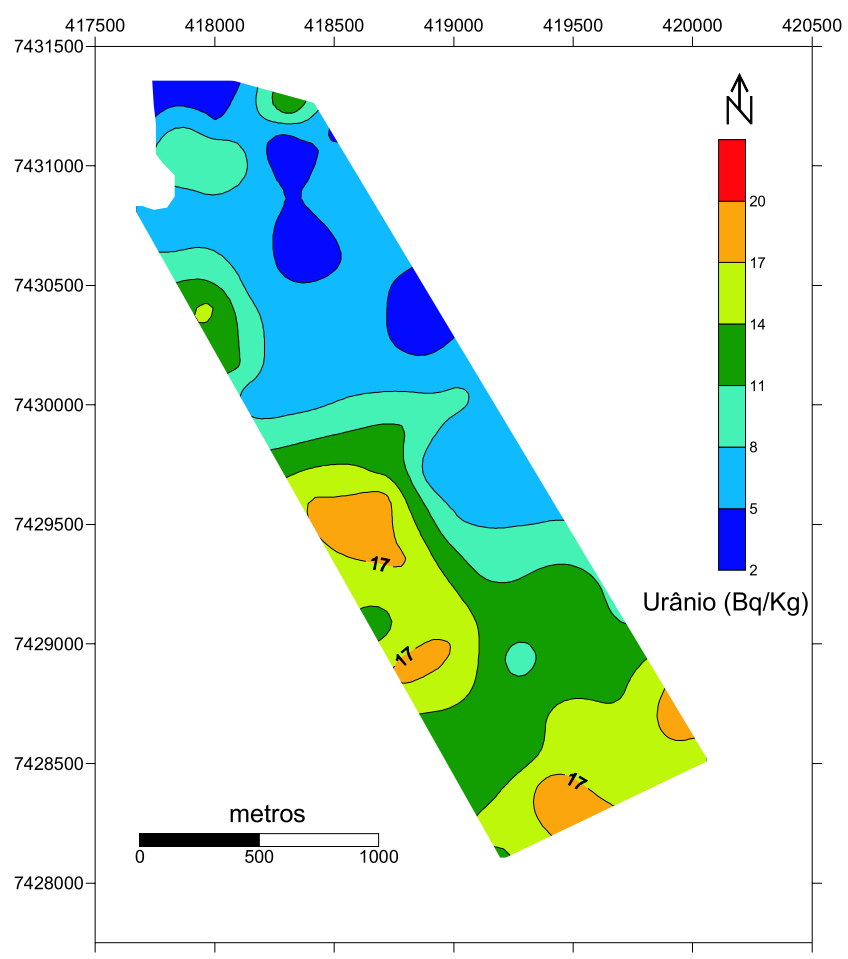

Figura 4 - Distribuiç̧ão espacial do urânio. 


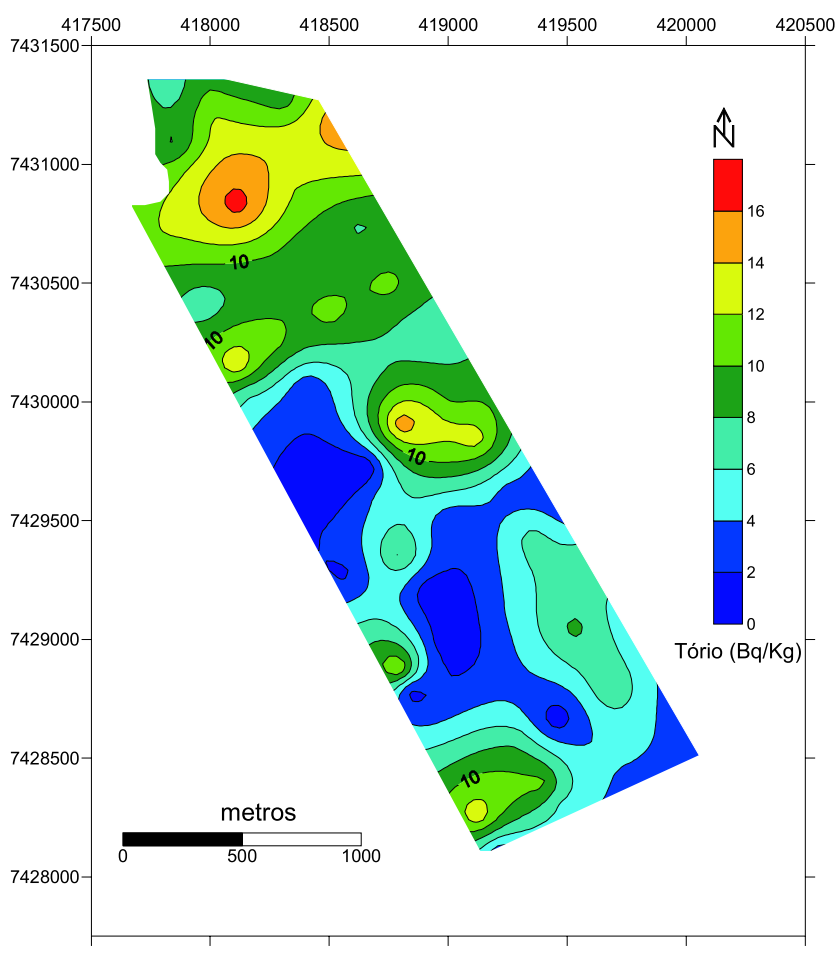

Figura 5 - Distribuição espacial do tório.

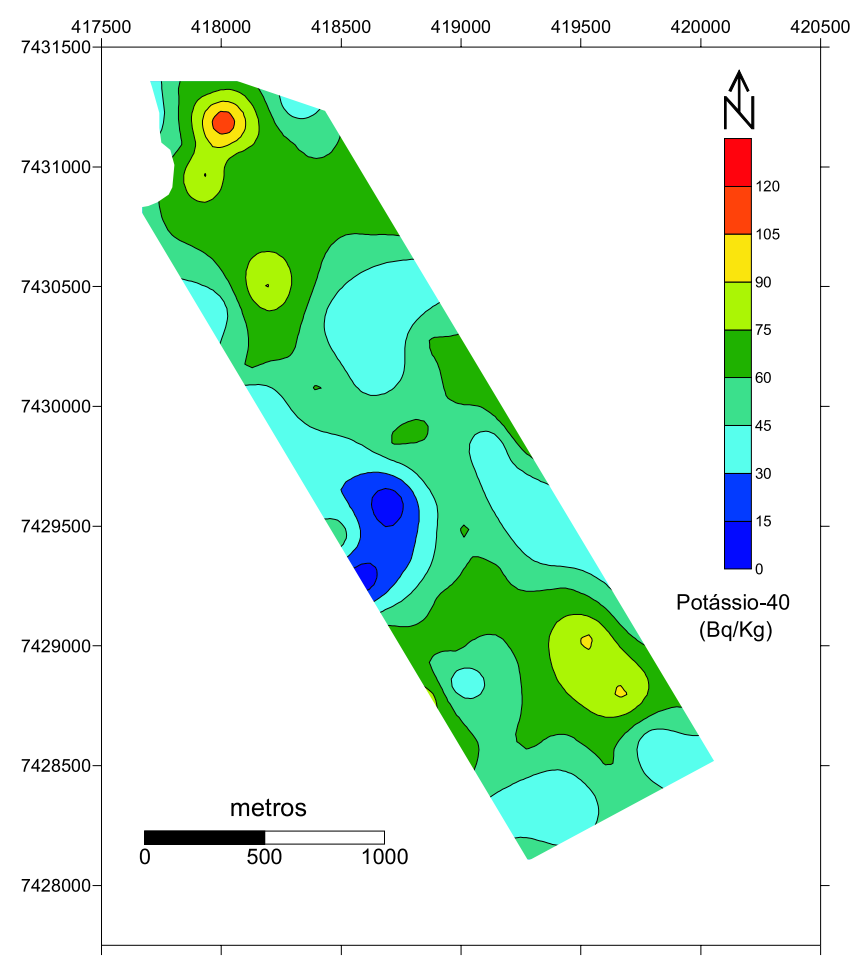

Figura 6 - Distribuição espacial do potássio. 
Tabela 5 - Estatística descritiva dos dados gamaespectrométricos, de resistividade aparente e dos teores argila $(n=77)$.

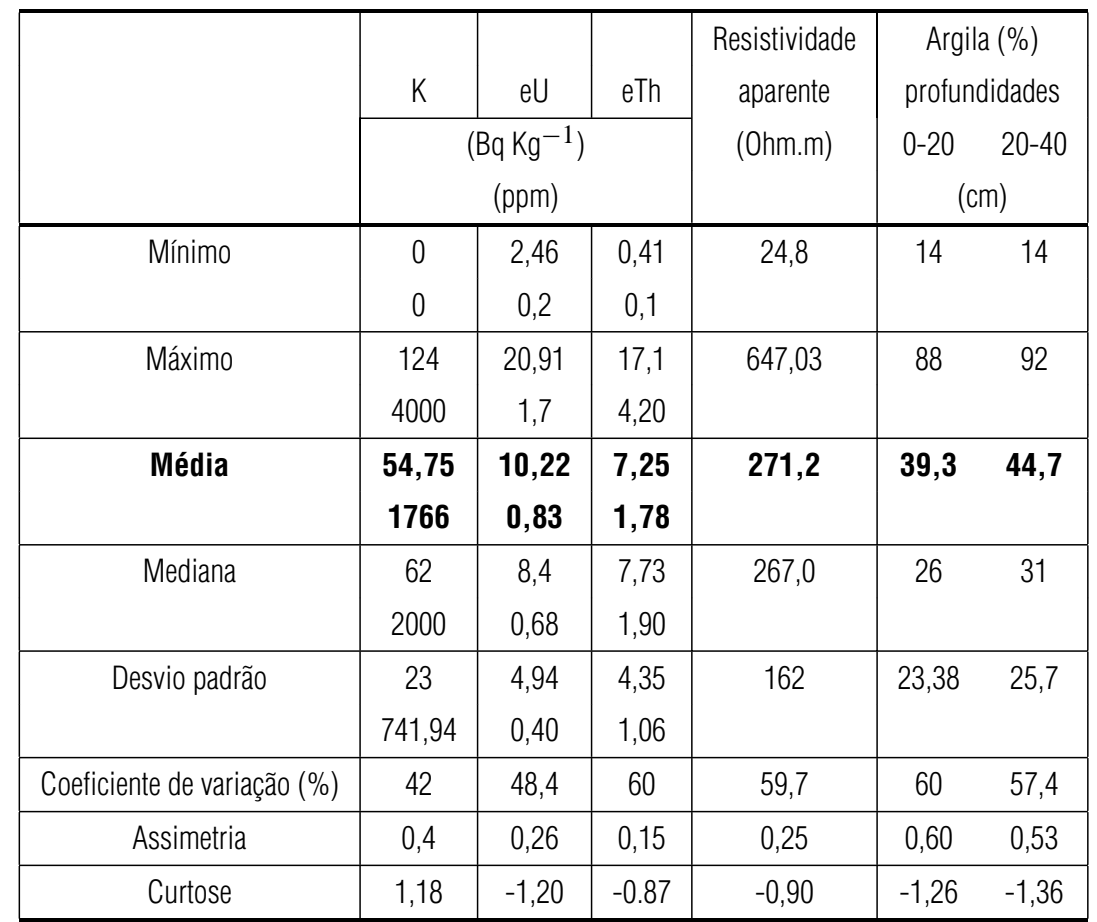

Tabela 6 - Síntese dos dados de suscetibilidade magnética por tipo de solo para as duas profundidades.

\begin{tabular}{|c|c|c|c|c|}
\hline \multirow{2}{*}{} & Areno/argiloso & Argilosos & Areno/argiloso & Argilosos \\
\cline { 2 - 5 } & \multicolumn{4}{|c|}{ Profundidades (cm) } \\
\cline { 2 - 5 } & $0-20$ & $0-20$ & $20-40$ & $20-40$ \\
\cline { 2 - 5 } & \multicolumn{4}{|c|}{$\left(\times 10^{-3}\right.$ SI) } \\
\hline Mínimo & 0,29 & 0,42 & 0,28 & 0,44 \\
\hline Máximo & 0,82 & 1,1 & 0,82 & 0,95 \\
\hline Média & $\mathbf{0 , 4 5}$ & $\mathbf{0 , 7}$ & $\mathbf{0 , 4 3}$ & $\mathbf{0 , 6 9}$ \\
\hline Desvio padrão & 0,12 & 0,16 & 0,12 & 0,14 \\
\hline Coeficiente de variação $(\%)$ & 26,6 & 22,9 & 27,9 & 20,3 \\
\hline Assimetria & 1,39 & 0,49 & 1,30 & 0,21 \\
\hline Curtose & 1,74 & $-0,2$ & 1,64 & $-1,05$ \\
\hline
\end{tabular}

reservas, foram tomadas aleatoriamente 20 medidas gamaespectrométricas com 3 repetições para cada ponto, sendo considerada a média das 3 medidas, cujo resumo estatístico é indicado na Tabela 9, do mesmo modo discriminando os solos argilosos do areno-argiloso, para efeito de comparação com a área cultivada. Assim, pode-se notar que as médias de K, eU e eTh dos solos argilosos da área agricultável (Tabela 9), cujos teores são respec- tivamente de 51,0, 14,9 e 4,61 $\mathrm{Bq} \mathrm{Kg}^{-1}$ (1645,1; 1,21 e 1,13 ppm) são maiores do que as respectivas concentrações médias nos solos das áreas virgens, ou seja 26,4, 1,41 e 1,81 Bq Kg-1 (851,6; 0,11 e 0,45 ppm). Diferenças tão acentuadas podem ser explicadas pelo aporte de fertilizantes agrícolas. Tais diferenças são comprovadas estatisticamente pelo teste $\mathbf{t}$ (Student). Comportamento semelhante ocorre também com o solo areno-argiloso, quando se 
Tabela 7 - Estatística descritiva dos dados geofísicos e dos teores de argila em solo areno-argiloso.

\begin{tabular}{|c|c|c|c|c|c|}
\hline & Potássio & Urânio & Tório & $\begin{array}{c}\text { Resistividade } \\
\text { aparente } \\
\text { (Ohm.m) }\end{array}$ & $\begin{array}{c}\text { Argila } \\
(\%)\end{array}$ \\
\cline { 2 - 3 } & \multicolumn{3}{|c|}{$\mathrm{Bq} / \mathrm{Kg}$} & 131,88 & 14,00 \\
\hline Mínimo & 31,00 & 2,46 & 0,81 & 647,03 & 47,00 \\
\hline Máximo & 124,00 & 14,76 & 17,09 & $\mathbf{3 6 7 , 5 6}$ & $\mathbf{2 5 , 2 0}$ \\
\hline Média & $\mathbf{5 7 , 2 8}$ & $\mathbf{7 , 0 3}$ & $\mathbf{9 , 0 3}$ & $\mathbf{3 6}$ & 7,40 \\
\hline Desvio padrão & 22,61 & 3,10 & 3,83 & 125,35 & 29,36 \\
\hline Coeficiente de variação (\%) & 39,47 & 44,10 & 42,41 & 34,10 & 2,14 \\
\hline Curtose & 1,77 & 0,29 & $-0,39$ & $-0,60$ & 2,43 \\
\hline Assimetria & 0,96 & 0,91 & $-0,05$ & 0,08 & 1,43 \\
\hline
\end{tabular}

Tabela 8 - Estatística descritiva dos dados geofísicos e dos teores de argila em solos argilosos.

\begin{tabular}{|c|c|c|c|c|c|}
\hline & Potássio & Urânio & Tório & \multirow{2}{*}{$\begin{array}{c}\text { Resistividade } \\
\text { aparente } \\
\text { (Ohm.m) }\end{array}$} & \multirow{2}{*}{$\begin{array}{c}\text { Argila } \\
(\%)\end{array}$} \\
\hline & \multicolumn{3}{|c|}{$\mathrm{Bq} / \mathrm{Kg}$} & & \\
\hline Mínimo & 0,00 & 8,61 & 0,41 & 24,79 & 46,00 \\
\hline Máximo & 93,00 & 20,91 & 13,43 & 336,43 & 92,00 \\
\hline Média & 51,00 & 14,96 & 4,61 & 128,23 & 73,58 \\
\hline Desvio padrão & 23,40 & 2,98 & 3,74 & 87,02 & 12,40 \\
\hline Coeficiente de variação (\%) & 45,88 & 19,92 & 81,13 & 67,86 & 16,85 \\
\hline Curtose & 0,03 & $-0,43$ & $-0,37$ & 0,05 & $-0,66$ \\
\hline Assimetria & $-0,28$ & $-0,35$ & 0,80 & 0,86 & $-0,42$ \\
\hline
\end{tabular}

confrontam os resultados obtidos na área agrícola com os correspondentes do trato sem contaminação, exceto pelo fato de que não existe diferença significativa entre as médias do eTh para ambas as áreas, conforme indicam letras iguais nas respectivas médias (Tabela 9).

Para a área virgem onde domina 0 solo areno-argiloso, a média do eU foi de $1,97 \mathrm{~Bq} \mathrm{Kg}^{-1}$ (0,16 ppm), portanto maior do que os $1,41 \mathrm{~Bq} \mathrm{Kg}^{-1}(0,11 \mathrm{ppm})$ dos solos argilosos. Já os teores de $\mathrm{K}$ e eTh no primeiro trato foram respectivamente de 41,9 e 8,91 Bq/Kg (1351,6 e 2,19 ppm), portanto maiores do que as médias nos solos argilosos, ou seja 26,4 e 1,81 Bq/Kg (851,6 e 0,44 ppm). Uma possível explicação reside na idade e na mineralogia dos respectivos solos. Os solos argilosos oriundos da Formação Serra Geral são mais velhos, intemperizados e conseqüentemente mais lixiviados, propiciando percolações de $\mathrm{K}$ e eTh no perfil. Nos solos de textura mista, originado do retrabalhamento das formações Serra Geral e Goio-Erê, sendo este último de textura arenosa, pode ter havido contribuição, para a sedimentação, de minerais com teores mais elevados de potássio e tório provenientes das áreas-fonte da Formação Goio-Erê.
A distribuição espacial dos radionuclídeos encontra-se nas Figuras 4, 5 e 6. Observa-se na Figura 4 do urânio, que a maior concentração de radioatividade ocorre nas partes mais argilosas onde ocorrem os solos Nitossolo Vermelho Eutrófico e o Latossolo Vermelho Eutroférrico (Figura 2).

A espacialização do tório (Figura 5), ao contrário, evidencia que a maior parte da radioatividade coincide com exposição do Latossolo Vermelho Distrofico (Figura 2), talvez pela permanência de minerais resistatos.

0 mapa do potássio (Figura 6) mostra que a parte mais radioativa se concentra na área com solo de textura mais arenosa, refletindo a possível presença de minerais contendo potássio, fato corroborado por Nascimento (2003). Também é possível realçar tal constatação, analisando-se a Figura 7, que exprime a relação $\mathrm{K} / \mathrm{U}$, onde se insere o Latossolo Vermelho Distrófico.

Os valores da radioatividade obtidos nas rochas eruptivas básicas (basaltos da Formação Serra Geral), foram tomados aleatoriamente em afloramentos não alterados e um resumo estatístico de 20 leituras, considerando-se a média de 3 leituras por ponto, está indicado na Tabela 10. Os teores médios de U e Th foram de 
Tabela 9 - Estatística descritiva dos radionuclídeos em solos sob floresta nativa $(\mathrm{n}=20)$.

\begin{tabular}{|c|c|c|c|c|c|c|}
\hline \multirow{2}{*}{} & \multicolumn{6}{|c|}{ Textura } \\
\cline { 2 - 7 } & \multicolumn{7}{|c|}{ Areno/argiloso } & \multicolumn{3}{c|}{ Argiloso } \\
\cline { 2 - 7 } & $\mathrm{K}$ & $\mathrm{eU}$ & $\mathrm{eTh}$ & $\mathrm{K}$ & $\mathrm{eU}$ & $\mathrm{eTh}$ \\
\cline { 2 - 7 } & \multicolumn{6}{|c|}{$\mathrm{Bq} \mathrm{Kg}^{-1}$} \\
\hline Mínimo & 0 & 0 & 7,32 & 0 & 0 & 0,4 \\
\hline Máximo & 93 & 6,15 & 11,8 & 62 & 2,46 & 3,66 \\
\hline Média(*) & $41,9 \mathrm{a}$ & $1,97 \mathrm{c}$ & $8,91 \mathrm{e}$ & $26,4 \mathrm{f}$ & $1,41 \mathrm{~h}$ & $1,81 \mathrm{j}$ \\
\hline Média(**) & $57,28 \mathrm{~b}$ & $7,03 \mathrm{~d}$ & $9,03 \mathrm{e}$ & $51,0 \mathrm{~g}$ & $14,9 \mathrm{i}$ & $4,61 \mathrm{k}$ \\
\hline Mediana & 31 & 1,85 & 8,5 & 31 & 1,23 & 1,63 \\
\hline Desvio padrão & 23,1 & 1,71 & 1,19 & 23,1 & 0,92 & 0,9 \\
\hline Coeficiente de variação $(\%)$ & 55,2 & 86,9 & 13,4 & 87,7 & 64,8 & 49,8 \\
\hline Assimetria & 0,15 & 0,81 & 0,87 & 0,25 & $-0,25$ & 0,39 \\
\hline Curtose & 0,08 & 0,47 & 0,47 & $-1,04$ & $-1,04$ & $-0,59$ \\
\hline
\end{tabular}

Médias seguidas de letras iguais não diferem significativamente a $5 \%$ pelo teste t. $\left({ }^{*}\right)$ média das testemunhas; $\left({ }^{\star \star}\right)$ média dos solos areno/argiloso e argilosos respectivamente.

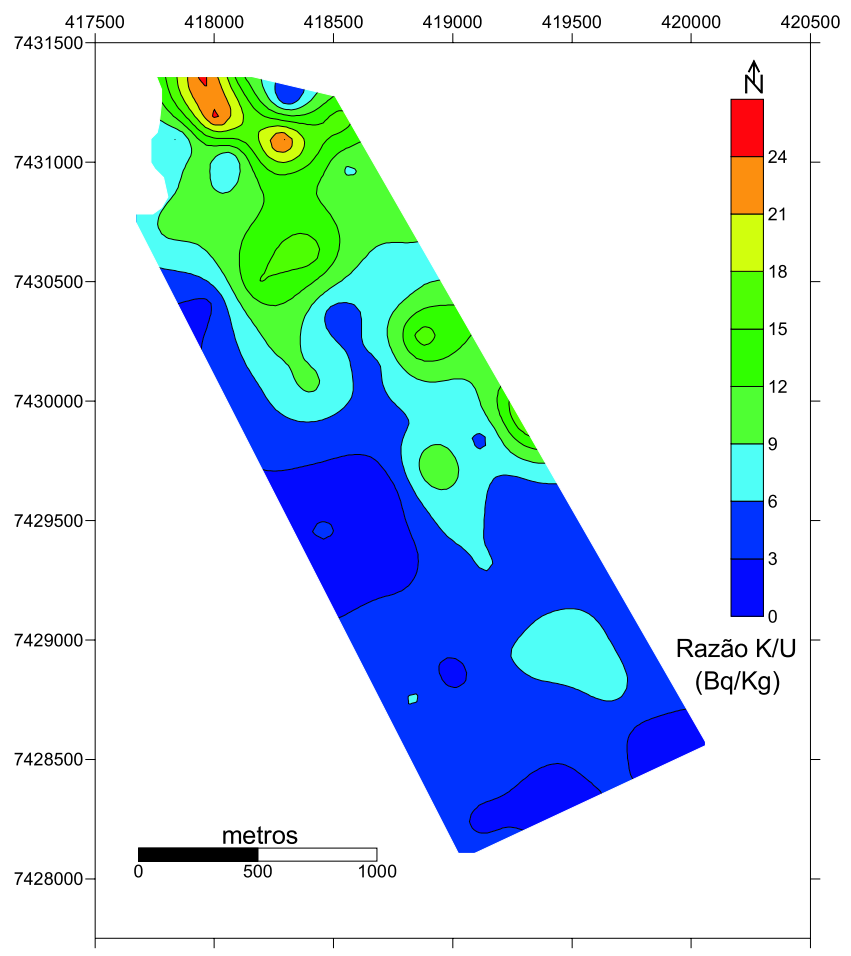

Figura 7 - Distribuição espacial da razão potássio/urânio. 
23,67 e 11,14 Bq Kg${ }^{-1}$ (1,92 e 2,74 ppm), respectivamente, os quais, quando comparados aos dados divulgados por Marques (1988), em derrame basáltico da Bacia do Paraná, mostram valores muito próximos para o U (26,81 $\mathrm{Bq} \mathrm{Kg}^{-1}, 2,18$ ppm), porém muito diferentes para $0 \mathrm{Th}\left(1,59 \mathrm{~Bq} \mathrm{Kg}^{-1} ; 0,39 \mathrm{ppm}\right)$.

Tabela 10 - Concentrações e estatísticas dos radionuclídeos em rochas eruptivas básicas.

\begin{tabular}{|c|c|c|c|}
\hline \multirow{2}{*}{} & Potássio & Urânio & Tório \\
\cline { 2 - 4 } & \multicolumn{3}{|c|}{$\mathrm{Bq} / \mathrm{Kg}$} \\
\hline Mínimo & 124 & 2,46 & 0,40 \\
\hline Máximo & 806 & 50,40 & 23,60 \\
\hline Média & $\mathbf{4 0 0}$ & $\mathbf{2 3 , 6 7}$ & $\mathbf{1 1 , 1 4}$ \\
\hline Desvio padrão & 191,1 & 13,62 & 6,42 \\
\hline Coeficiente de variação (\%) & 47,80 & 57,50 & 57,60 \\
\hline Assimetria & 0,17 & 0,39 & 0,23 \\
\hline Curtose & $-0,26$ & $-0,54$ & $-0,40$ \\
\hline
\end{tabular}

Dickson \& Scott (1997), enfatizaram que numa mesma classe de rocha, pode haver ampla variação das concentrações dos radioelementos. Os referidos autores exibiram teores de elementos radioativos em vários tipos de rochas da Austrália, mostrando que devido a grande dispersão das concentrações em cada classe, não é possível estabelecer uma classificação petrográfica com base no conteúdo de radionuclídeos.

De acordo com Wilford et al. (1997), durante o intemperismo químico e físico, os radioelementos são liberados da rocha, redistribuídos e incorporados ao regolito/solo. Em muitos casos, as características dos elementos radioativos de regolitos podem em muito diferir da rocha-mãe, devido à reorganização textural e geoquímica que ocorre no perfil intemperizado.

As Figuras 8, 9 e 10 mostram a distribuição dos radionuclídeos nos perfis verticais dos três tipos de solos mapeados na área da pesquisa, cujas medidas foram feitas diretamente nas paredes dos experimentos com intervalos de $20 \mathrm{em} 20 \mathrm{~cm}$. As concentrações dos radionuclídeos no perfil do Latossolo VermeIho Distrófico (Figura 8), de textura areno-argilosa, mostram-se praticamente constantes nos primeiros $20 \mathrm{~cm}$, notando-se, a partir daí, um incremento progressivo do potássio até a profundidade de $60 \mathrm{~cm}$, o mesmo acontecendo, aproximadamente, com 0 urânio e 0 tório. Entre 60 e $80 \mathrm{~cm}$ os valores de $\mathrm{K}$ decaem, enquanto os de $\mathrm{U}$ e Th praticamente permanecem constantes. A partir de $80 \mathrm{~cm}$ e até 0 final da amostragem, os índices de $\mathrm{K}$ tendem a aumentar levemente para assumir valores semelhantes aos primeiros $20 \mathrm{~cm}$ do perfil. Entretanto, os valores de $\mathrm{U}$ e Th tendem a diminuir com 0 aumento da profundidade, sobretudo para o último, denotando maiores retenções destes radioelementos em relação à superfície.

Para o perfil do Nitossolo Vermelho Eutrófico (Figura 9), os teores de $\mathrm{U}$ e Th aumentam até os primeiros $40 \mathrm{~cm}$, permanecem constantes até os $80 \mathrm{~cm}$, e diminuem progressivamente até $160 \mathrm{~cm}$, quando, a partir deste nível, as concentrações crescem no sentido do horizonte $C$, na medida em que se aproxima do material de origem destes solos, denotando depleção de $\mathrm{U}$ e Th desde a rocha-fonte até a superfície. Comportamento semelhante é observado no perfil do potássio, onde a partir de 1,6 m, os teores vão aumentando paulatinamente no sentido do horizonte $C$. Os perfis dos radioelementos no Latossolo Vermelho Eutroférrico (Figura 10) exibem desempenho semelhante, observando-se enriquecimento dos teores a partir de 2,2 $\mathrm{m}$ de profundidade até 0 horizonte $\mathrm{C}$.

Dickson \& Scott (1997) observaram mudanças significativas dos elementos radiogênicos em solos oriundos de rochas máficas na Austrália. 0 basalto originou solos com perdas de até $50 \%$ de Ke aumento do $U$ e do Th, próximos aos teores de rochas félsicas. Ainda segundo aqueles autores, em áreas dominadas por solos mais profundos, fortemente intemperizados, também derivados de rochas basálticas, houve depleção de $\mathrm{K}$ e as respostas do $\mathrm{U}$ e do Th foram semelhantes àquelas obtidas para solos derivados de rochas félsicas. Tal padrão de distribuição difere, como visto, do comportamento dos radionuclídeos nos perfis dos solos estudados, possivelmente pela localização dos mesmos em região subtropical úmida, com precipitações médias de 1492 mm/ano (Rufino et al., 1993), aliado ao intemperismo físico/químico, principalmente do Latossolo Vermelho Eutroférrico, mais velho e mais profundo, em contraposição a climas mais secos, como na Austrália, acarretando retenção dos radioelementos nos perfis dos solos mencionados. Condição climática análoga ao da Austrália é aquela que ocorre em algumas partes do nordeste brasileiro, onde determinados solos acumulam teores elevados de sais em subsuperfície, oriundos do processo de capilaridade.

Dowdall \& O'Dea (2002) estudando a radioatividade em perfis de solos orgânicos na Irlanda, observaram que há um acréscimo de U nos perfis onde a oxidação da matéria orgânica é significativamente reduzida, o que acontece a partir de aproximadamente $15-20 \mathrm{~cm}$ de profundidade, onde a ausência de oxigênio origina um ambiente predominantemente redutor, desacelerando a decomposição da matéria orgânica pelos microorganismos do solo, e, conseqüentemente, aumentando a capacidade de troca catiônica de tais solos, o que culminaria com 0 aumento da retenção do U.

Um resumo estatístico dos teores de radionuclídeos tomados por amostragens aleatórias em fertilizantes fosfatados (duas 


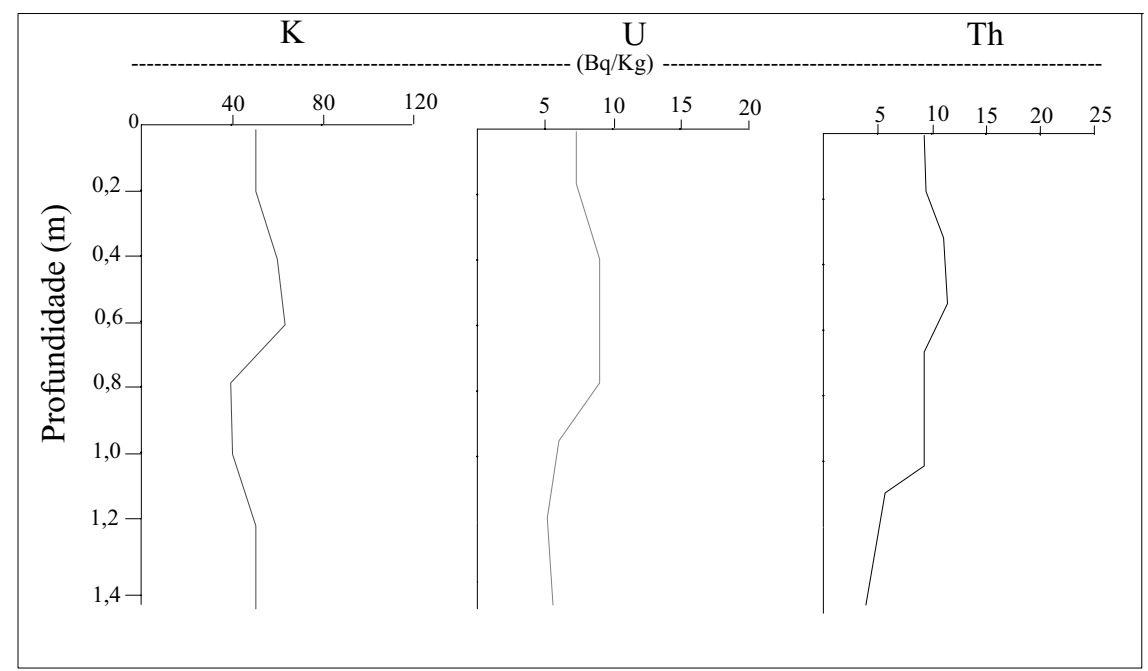

Figura 8 - Distribuição de K, U e Th no perfil do Latossolo Vermelho Distrófico.

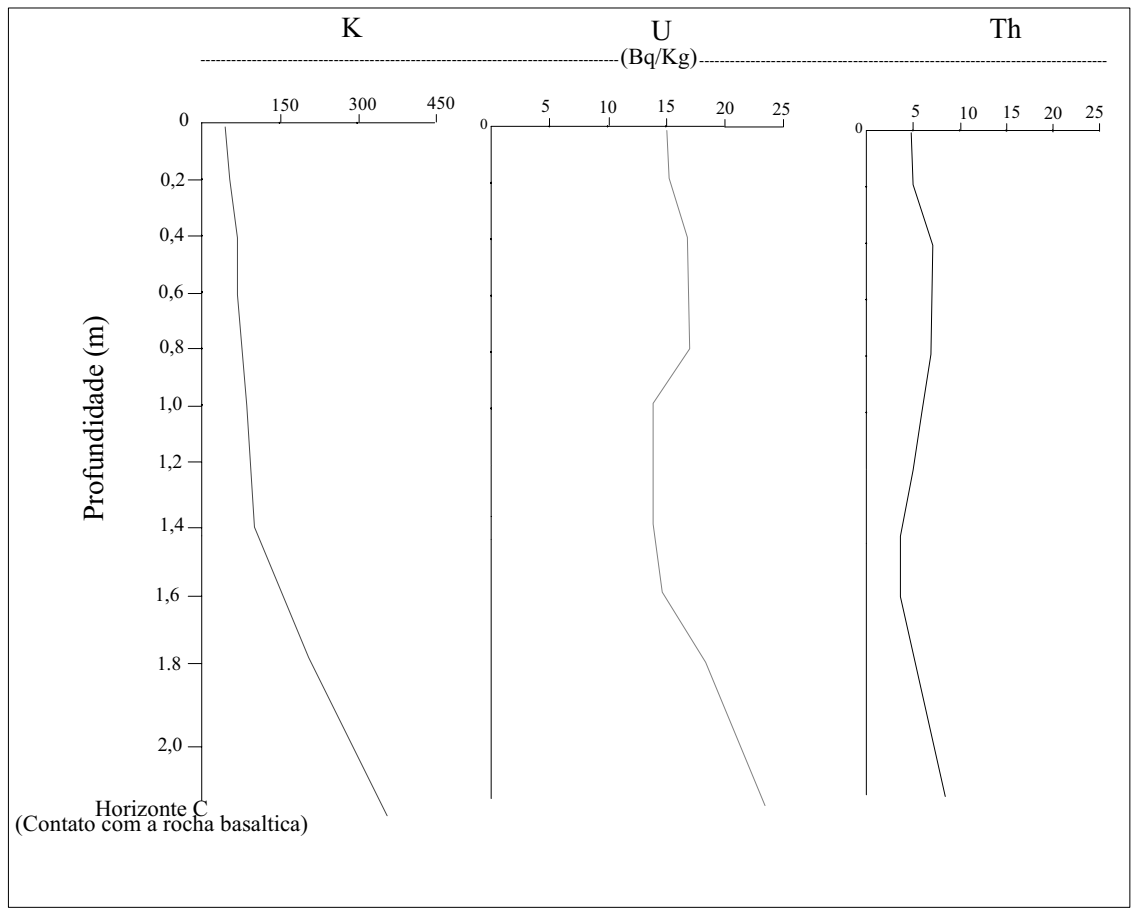

Figura 9 - Distribuição de K, U e Th no perfil do Nitossolo Vermelho Eutrófico.

formulações) e pilhas de gesso, num total de 20 determinações, é indicado na Tabela 11, a qual denota grande variabilidade nas concentrações, principalmente dos adubos. Para estes, as variações de K, U e Th foram de 603,0 a 522,4; de 647,6 a 58,0 e de 753,9 a 10,82 Bq Kg (19451,6 a 16851,6; 52,65 a 4,7 e 185,2 a 2,66 ppm), respectivamente, cujas médias foram de 562,7; 352,8 e 382,3 $\mathrm{Bq} \mathrm{Kg}^{-1}$ (18151,6; 28,7 e 93,9 ppm).
Paschoa et al. (1984), analisaram as concentrações de U (Tabela 12) em amostras de vários tipos de adubos e obtiveram uma média de 1044,26 Bq Kg${ }^{-1}$ (84,91 ppm); Yamazaki \& Geraldo (2003), estudando os teores de U em amostras de adubos NPK oriundas de diversos fabricantes brasileiros (Tabela 13), determinaram variações entre 63,59 e $667,89 \mathrm{~Bq} \mathrm{Kg}^{-1}$ (5,17 e 54,3 ppm), com média de 333,25 $\mathrm{Bq} \mathrm{Kg}^{-1}$ (27,09 ppm). 


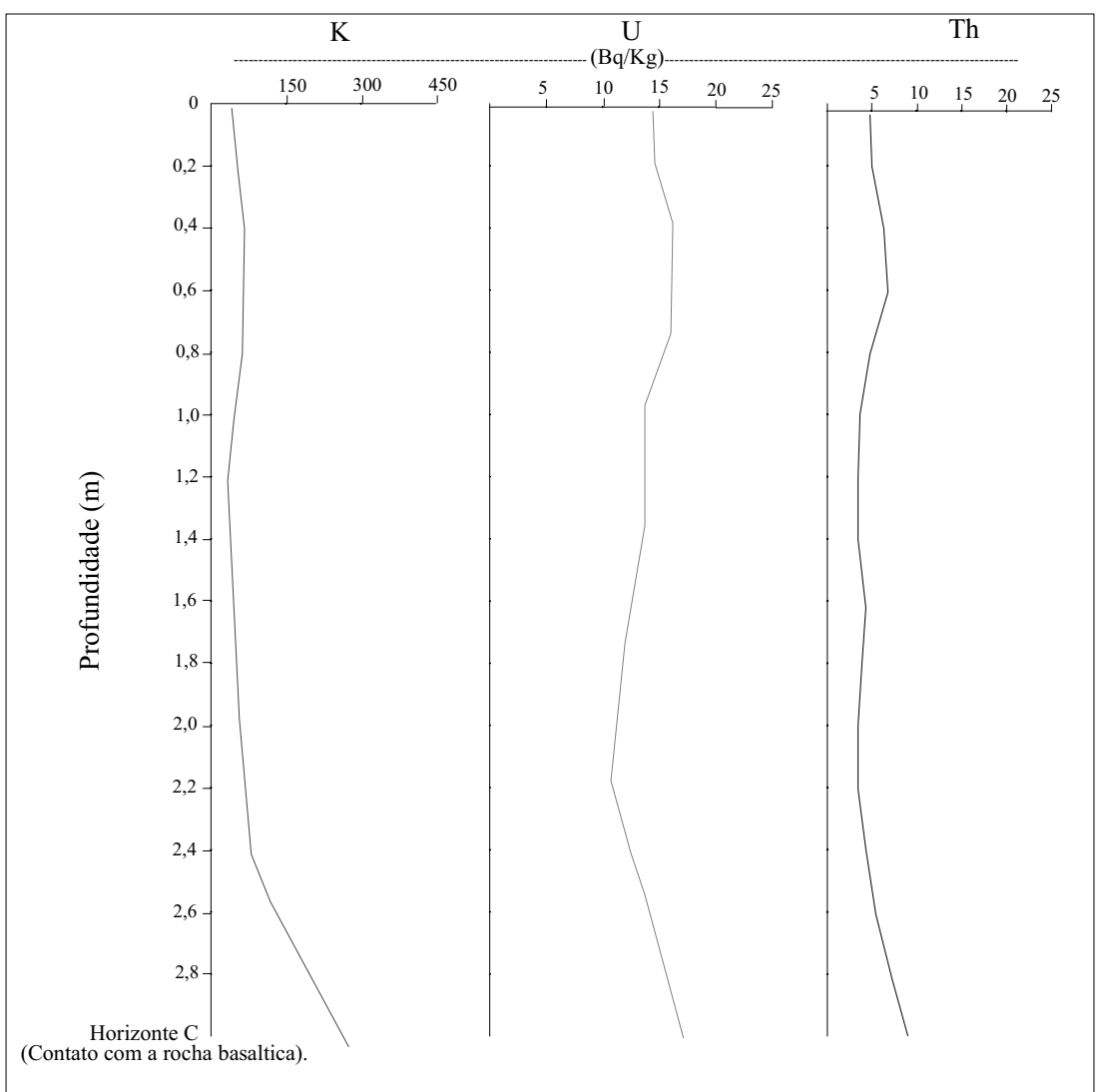

Figura 10 - Distribuição de K, U e Th no perfil do Latossolo Vermelho Eutroférrico.

Tabela 11 - Estatísticas dos radionuclídeos em amostras de adubos e gesso $(n=20)$.

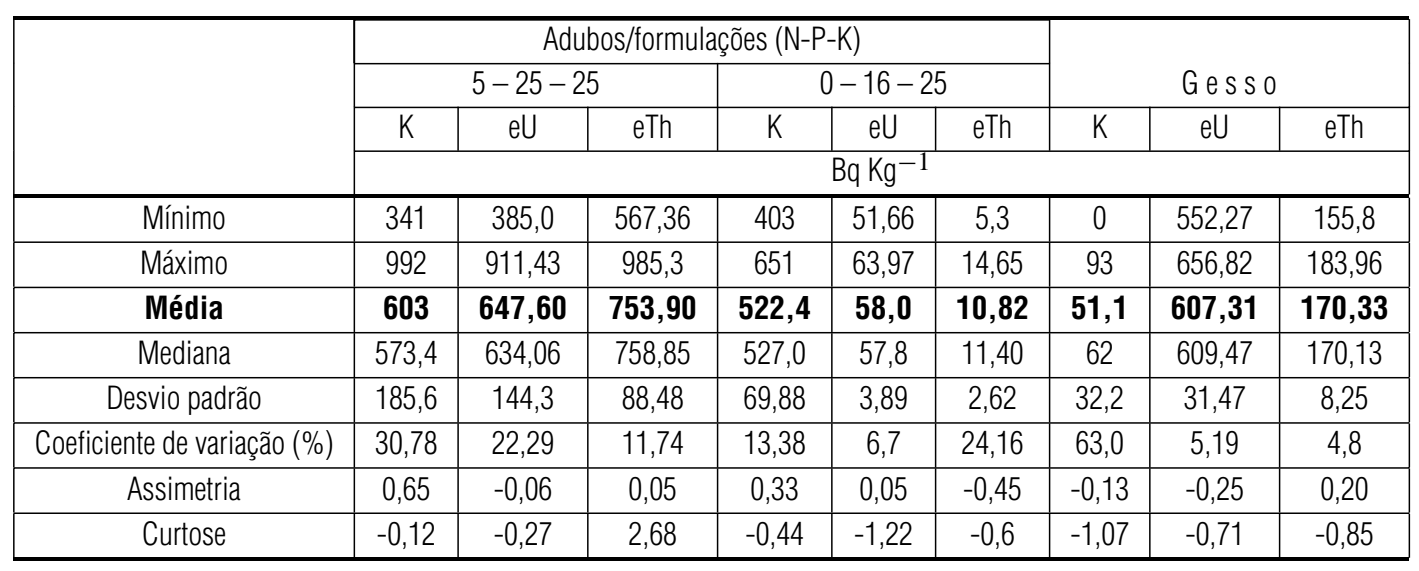

Segundo Pfister et al. (1976), as diferenças nas concentrações da radioatividade de vários produtos, são atribuídas principalmente ao modo de fracionamento durante a reação química na fase de acidulação da produção do ácido fosfórico. Produtos como o MAP (mono amônio fosfato), mostraram que as concentrações de rádio são dez vezes maiores do que a de urânio, face ao processo de fabricação do referido fertilizante, 0 qual utiliza amônia, que por sua vez não reage com a rocha fosfática, ao contrário do ácido fostórico que é rico em urânio. As apatitas nos concentrados fostáticos são destruídas pela ação do ácido 
Tabela 12 - Teores de urânio em alguns fertilizantes comercializados no Brasil.

\begin{tabular}{|c|c|c|c|}
\hline Origem das rochas & $\begin{array}{c}\text { Tipo de adubo } \\
(\mathrm{n}=\text { amostras })\end{array}$ & $\begin{array}{c}\text { Média e desvio padrão } \\
(\mathrm{U} \text { em ppm) }\end{array}$ & $\begin{array}{c}\text { Média } \\
(\mathrm{U} \text { em Bq/Kg) }\end{array}$ \\
\hline Araxá & Concentrado (3) & $212 \pm 22$ & 2607 \\
Tapira & Concentrado (3) & $21 \pm 3$ & 258,3 \\
Araxá & FAC (3) & $209 \pm 21$ & 2570 \\
Araxá & CAC (3) & $110 \pm 13$ & 1353 \\
Araxá & FAPS (3) & $88 \pm 8$ & 1082,4 \\
Araxá & SSP (8) & $94 \pm 10$ & 1156,2 \\
Tapira & SSP (4) & $24 \pm 3$ & 295,2 \\
Araxá & SST (5) & $100 \pm 8$ & 1230 \\
Tapira & SST (4) & $30 \pm 3$ & 369 \\
Tapira & MAP (5) & $11 \pm 2$ & 135,3 \\
Tapira & DAP (5) & $35 \pm 5$ & 430,5 \\
\hline Média & & $\mathbf{8 4 , 9 1}$ & $\mathbf{1 0 4 4 , 2 6}$ \\
\hline
\end{tabular}

Fonte: Adaptado de Paschoa et al. (1984).

Tabela 13 - Concentração de urânio para diferentes fabricantes e formulações de NPK (\%) em alguns adubos produzidos no Brasil.

\begin{tabular}{|c|c|c|c|c|c|}
\hline Fabricante & $\mathrm{N}$ & $P$ & K & Urânio(ppm) & Urânio (Bq/Kg) \\
\hline Nitrobras & 10 & 10 & 10 & $28,45 \pm 0,60$ & 349,95 \\
\hline Nitrobras & 04 & 14 & 08 & $29,50 \pm 0,25$ & 362,85 \\
\hline Manah & 13 & 13 & 28 & $19,34 \pm 0,74$ & 237,88 \\
\hline Manah & 04 & 30 & 20 & $26,10 \pm 0,55$ & 321,03 \\
\hline Ultrafertil & 06 & 30 & 24 & $22,26 \pm 0,78$ & 273,80 \\
\hline Ultraverde & 10 & 10 & 10 & $30,60 \pm 0,42$ & 376,38 \\
\hline Serrana & 04 & 14 & 08 & $54,3 \pm 2,3$ & 667,89 \\
\hline Mitsui & 04 & 14 & 08 & $34,29 \pm 0,79$ & 421,77 \\
\hline Fertibras & 10 & 10 & 10 & $20,81 \pm 0,45$ & 255,96 \\
\hline Nutrisafra & 04 & 14 & 08 & $38,57 \pm 0,85$ & 474,41 \\
\hline Fertiliza & 02 & 20 & 20 & $15,72 \pm 0,34$ & 193,56 \\
\hline Heringer & 03 & 15 & 15 & $5,17 \pm 0,27$ & 63,59 \\
\hline Média & & & & 27,09 & 333,25 \\
\hline
\end{tabular}

sulfúrico durante a fabricação dos superfosfatos. Entretanto, 0 urânio permanece como sulfato de uranila e sulfato uranoso, ambos solúveis em água. Na ausência de matéria orgânica e em solos arenosos, o U geralmente é móvel e transportado como um complexo de carbonato hexavalente ou como íon uranila divalente (Rothbaum et al., 1979).

Os teores médios dos radionuclídeos encontrados nas amostras de gesso foram de 51,1; 607,31 e 170,33 $\mathrm{Bq} \mathrm{Kg}^{-1}$ (1648,4; 49,4 e 41,9 ppm) de K, eU e eTh, respectivamente (Tabela 11). Bolivar et al. (1995) indicaram atividade média de $600 \mathrm{~Bq} \mathrm{Kg}^{-1}$
(48,8 ppm) de $\mathrm{U}$ em depósitos de gesso, enquanto Aguirre et al. (1995) citaram intervalos de 4,3 a $502 \mathrm{~Bq} \mathrm{Kg}^{-1}$ (0,34 a 40,8 ppm) de $\mathrm{U}$ e de 2,4 a $156 \mathrm{~Bq} \mathrm{Kg}^{-1}$ (0,6 a 38,3 ppm) de Th em sedimentos de rios próximos a fábricas de fertilizantes. Mazzili et al. (2000), amostraram porções de gesso de quatro fabricantes (Tabela 14) e detectaram valores médios 17,75; 27,75 e $128 \mathrm{~Bq} \mathrm{Kg}^{-1}$ (572,6; 2,25 e 31,5 ppm), respectivamente de K, U e Th.

A utilização do gesso na agricultura, tem por finalidade fornecer cálcio e enxofre para as plantas nos horizontes subsuperficiais. Ao contrário do calcário que tem por objetivo corrigir 0 
Tabela 14 - Concentrações de radionuclídeos $\left(\mathrm{Bq} \mathrm{Kg}^{-1}\right)$ obtidos por espectrometria de raios gama em amostras de gesso e rochas fosfáticas.

\begin{tabular}{|c|c|c|c|c|}
\hline Matéria-prima & Fabricante & ${ }^{238} \mathrm{U}$ & ${ }^{232} \mathrm{Th}$ & $\mathrm{K}$ \\
\hline Gesso & $\mathrm{A}$ & & & \\
Média e DP & & $42 \pm 6$ & $175 \pm 23$ & $25 \pm 13$ \\
Variação & & $35-47$ & $148-190$ & $12-39$ \\
\hline Rocha fosfática & & & & \\
Média e DP & & $1128 \pm 498$ & $245 \pm 35$ & $24 \pm 4$ \\
Variação & & $776-1480$ & $220-270$ & $21-27$ \\
\hline Gesso & $\mathrm{B}$ & & & \\
Média e DP & & $17 \pm 5$ & $156 \pm 38$ & $24 \pm 16$ \\
Variação & & $13-22$ & $129-200$ & $<4.2-35$ \\
\hline Rocha fostática & & & & \\
Média e DP & & $164 \pm 20$ & $256 \pm 81$ & $29 \pm 10$ \\
Variação & & $148-187$ & $197-349$ & $21-41$ \\
\hline Gesso & $\mathrm{C}$ & & & \\
Média e DP & & $41 \pm 24$ & $174 \pm 17$ & $18 \pm 1$ \\
Variação & & $23-68$ & $155-188$ & $<4.2-1.8$ \\
\hline Rocha fostática & & & & \\
Média e DP & & $434 \pm 69$ & $244 \pm 40$ & $18 \pm 11$ \\
Variação & & $355-485$ & $203-282$ & $4.8-2.5$ \\
\hline Gesso & D & & & \\
Média e DP & & $11 \pm 2$ & $7 \pm 1$ & $<4.2$ \\
\hline Média do gesso & & $\mathbf{2 7 , 7 5}$ & $\mathbf{1 2 8}$ & $\mathbf{1 7 , 7 5}$ \\
Média da rocha fosfática & & $\mathbf{5 7 5 , 3 3}$ & $\mathbf{2 4 8 , 3 3}$ & $\mathbf{2 3 , 6 7}$ \\
\hline
\end{tabular}

Fonte: Adaptado de Mazzilli et al. (2000). DP = desvio padrão.

pH dos solos, fornecendo cálcio e magnésio, o gesso percola no perfil fazendo com que as plantas desenvolvam o seu sistema radicular, explorando maior volume de solo e, conseqüentemente, nutrientes e água, como anteriormente referido. 0 problema na percolação de gesso é o conteúdo de elementos radioativos, que, com o tempo, além de ser incrementado, pode ser lixiviado para partes mais profundas dos solos e, em decorrência, para 0 lençol freático.

\section{Taxas de radiação (dose)}

Na Tabela 15 encontram-se as estimativas das taxas de radiação (dose), derivadas dos teores de potássio, urânio e tório. As maiores emanações de radioatividade advém dos adubos e do gesso, 69,45 e $34,07 \mu \mathrm{R} / \mathrm{h}$, respectivamente. As menores taxas são oriundas das áreas sob floresta nativa. A área cultivada emana mais radiação do que os tratos virgens, evidenciando que 0 uso 0 acúmulo de fertilizantes fosfatados são responsáveis por maiores doses.
As doses foram calculadas pelo somatório das contribuições do potássio, do urânio e do tório, em $\mu \mathrm{R} / \mathrm{h}$, objetivando compará-las com a dose máxima permitida, a qual é superior a 300 $\mathrm{mR} /$ semana (Sheriff, 1999) ou $1786 \mu \mathrm{R} / \mathrm{h}$. Nascimento \& Ferreira (2003), tomaram medidas gamaespectrométricas em experimento agrícola conduzido pela Embrapa/Planaltina-DF, e constataram que a adição de fertilizantes, incluindo o carbonatito, elevou os teores de $\mathrm{K}$, eU e eTh, e, conseqüentemente, a taxa da radioatividade natural nas parcelas experimentais, cuja maior dose advém do carbonatito, com 34,90 $\mu \mathrm{R} / \mathrm{h}$, semelhante aos valores obtidos nas amostras de gesso, 34,07 $\mu \mathrm{R} / \mathrm{h}$, determinados neste trabalho.

\section{Resistividade aparente e teores de argila dos solos}

Os valores da resistividade aparente da área total constam da Tabela 5 , juntamente com os dados gamaespectrométricos. No entanto, a resistividade aparente calculada para os solos de textura 
Tabela 15 - Taxas de radiação (dose) calculadas a partir do valor médio para cada um dos radionuclídeos.

\begin{tabular}{|c|c|c|c|c|c|c|c|}
\hline \multirow{2}{*}{ Variáveis } & \multicolumn{3}{|c|}{$\mathrm{K}$} & \multicolumn{2}{|c|}{$\mathrm{U}$} & \multicolumn{3}{|c|}{ Th } & Soma \\
\cline { 2 - 8 } & $\%$ & micro R/h & $\mathrm{ppm}$ & $\mathrm{micro} / \mathrm{h}$ & $\mathrm{ppm}$ & $\mathrm{micro} \mathrm{R} / \mathrm{h}$ & micro R/h \\
\hline Adubo (5-25-25) & 1,94 & 2,29 & 52,65 & 26,22 & 185,23 & 40,94 & 69,45 \\
\hline Adubo (0-16-25) & 1,68 & 1,98 & 4,72 & 2,35 & 2,66 & 0,59 & 4,92 \\
\hline Gesso & 0,2 & 0,24 & 49,37 & 24,58 & 41,85 & 9,25 & 34,07 \\
\hline Solos em geral & 0,17 & 0,20 & 0,83 & 0,41 & 1,78 & 0,39 & 1,0 \\
\hline Solos argilosos & 0,16 & 0,19 & 1,22 & 0,61 & 1,13 & 0,25 & 1,05 \\
\hline Solo areno/argiloso & 0,18 & 0,21 & 0,57 & 0,28 & 2,21 & 0,49 & 0,98 \\
\hline Solo areno/argiloso (floresta nativa) & 0,13 & 0,15 & 0,16 & 0,08 & 2,19 & 0,48 & 0,71 \\
\hline Solos argilosos (floresta nativa) & 0,08 & 0,09 & 0,12 & 0,06 & 0,45 & 0,10 & 0,25 \\
\hline Rochas & 1,29 & 1,52 & 1,92 & 0,96 & 2,73 & 0,60 & 3,08 \\
\hline
\end{tabular}

Fatores de conversão: 1\% de $\mathrm{K}=1,18$ micro R/h; 1 ppm de eU = 0,498 micro R/h; 1 ppm de eTh = 0,221 micro R/h (Fonte: Sheriff, 1999).

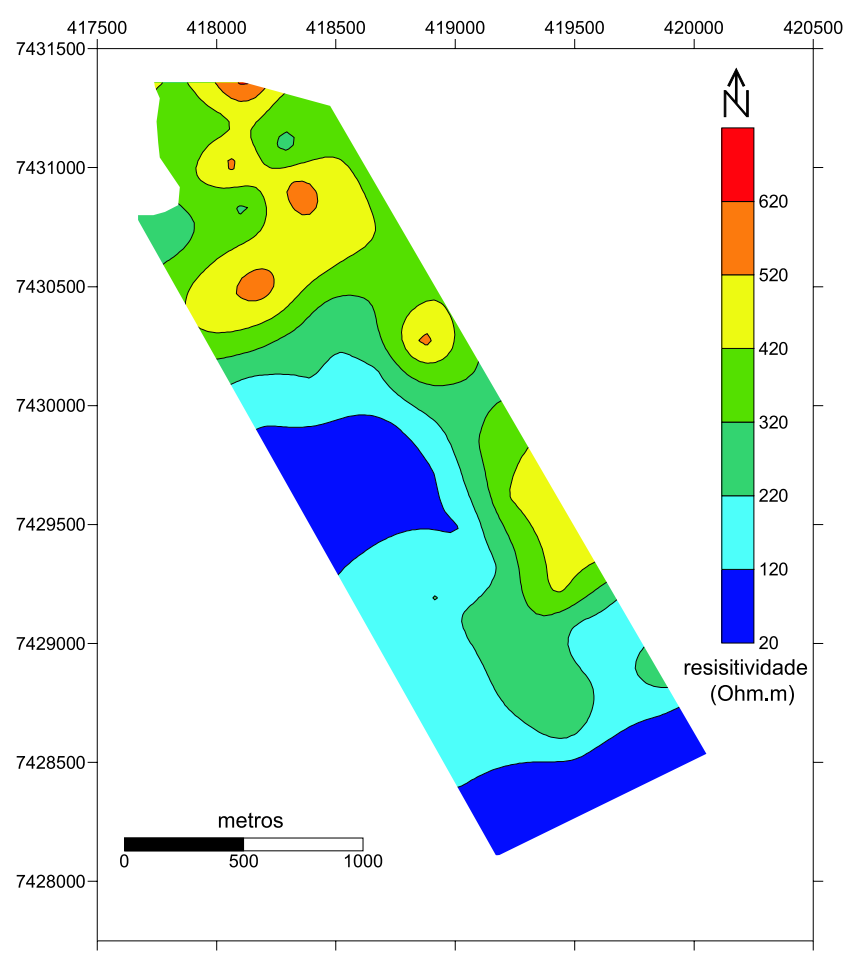

Figura 11 - Distribuição espacial da resistividade aparente

mista e argilosos pode ser vista nas Tabelas 7 e 8, respectivamente. Os valores de resistividade aparente obtidos referem-se a uma profundidade aproximada de $50 \mathrm{~cm}$ (Nascimento et al., 2004), decorrente do espaçamento entre os eletrodos de corrente e de potencial e do arranjo utilizado. Os solos argilosos apresentaram resistividade média de 128,23 0hm.m, enquanto para os solos de textura mista a média foi de 367,56 0hm.m, portanto maior do que os primeiros.
A Figura 11 mostra a distribuição espacial dos valores de resistividade aparente. A variação (entre 24,8 e 647,03 0hm.m, Tabelas 7 e 8), é compatível com os teores de argila e areia para as duas profundidades investigadas $(0-20$ e $20-40 \mathrm{~cm})$. As partes mais argilosas apresentam as mais baixas resistividades, ao contrário dos tratos mais arenosos, como era de se esperar. Comparando-se os mapas de solos da Figura 2, de argila (Figuras 12 e 13) e de resistividade aparente (Figura 11), fica clara a 
influência da textura em relação à resistividade, ou seja, solos de textura mais fina, facilitam a passagem da corrente elétrica, como indicam índices negativos (inversos) de correlação linear, obtidos por regressão, entre a resistividade aparente e os teores de argila para as duas profundidades $(r=-0,72 \mathrm{e}-0,74$, para $0-20$ e 20-40 cm, respectivamente).

Robain et al. (1996) utilizaram arranjo de eletrodos com espaçamento de $0,1 \mathrm{~m}$, visando obter medidas de resistividade para descrição de perfis de solos Lateríticos na República de Camarões. Nascimento et al. (2004), encontraram valores de resistividade aparente para solos argilosos de Brasília-DF, entre 8.000 e 10.000 Ohm.m, enquanto para os arenosos verificaram uma variação de 20.000 à 60.000 0hm.m.

A comparação da distribuição espacial da resistividade aparente (Figura 11) com 0 mapa de solos (Figura 2) mostra uma nítida discriminação dos solos argilosos dos de textura mista. Procedimento análogo foi utilizado por Banton et al. (1997), que efetuaram medidas de resistividade em solos agrícolas no Canadá, objetivando correlacioná-las com a textura. Neste sentido, o mapa de resistividade aparente foi utilizado como ferramenta importante na elaboração do mapa de solos, principalmente para delimitar os contornos das unidades pedológicas.

Quando da tomada dos dados de resistividade aparente, os solos apresentavam boa umidade em relação à capacidade de campo. Entretanto, é possível que mesmo em períodos mais secos, pelo fato do produtor utilizar o sistema de plantio direto (não se faz o revolvimento da terra), a cobertura dos restos culturais proporcione um isolamento térmico dos solos, e, conseqüentemente, a perda de água por evapotranspiração é sensivelmente reduzida. Os solos argilosos, por terem maior volume de microporos e maior superfície específica, perdem menos água por gravidade, ao contrário dos arenosos onde o volume de microporos é menor, do que decorre a percolação mais rápida da água no perfil dos solos.

Comparando-se os teores de argila entre as camadas de 0-20 e 20-40 cm, nota-se que os mesmos aumentam com a profundidade, como pode ser constatado na Tabela 5, assim como pela observação das Figuras 12 e 13. Isto reflete a influência da litologia mais feldspática na origem dos solos argilosos, derivados da Formação Serra Geral (Embrapa, 1984; Fernandes \& Coimbra, 2000).

\section{Susceptibilidade magnética dos solos}

De acordo com a Tabela 6 os solos argilosos apresentam maior susceptibilidade magnética, quando comparados ao solo arenoargiloso, como era de se esperar, em decorrência da maior dis- ponibilidade de minerais magnéticos nos primeiros. Os valores médios para os solos argilosos, nas duas profundidades, foram de 0,7 e $0,69\left(\times 10^{-3} \mathrm{SI}\right)$, respectivamente, e para os de textura mista foram de 0,45 e $0,43\left(\times 10^{-3} \mathrm{SI}\right)$.

Como a litologia nas áreas de contato é composta basicamente por rochas eruptivas básicas, originando solos de textura argilosa como o Nitossolo Vermelho Eutrófico e o Latossolo Vermelho Eutroférrico (Figura 2), ricos em minerais magnéticos (Vieira et al., 1988), torna-se evidente que a resposta magnética de tais solos é maior do que no Latossolo Vermelho Distrófico de textura areno-argilosa, cujo material de origem é composto pelo retrabalhamento das formações Serra Geral e Goio-Erê, esta última de textura arenosa.

É importante observar uma forte relação espacial entre os mapas de suscetibilidade magnética (Figuras 14 e 15), de resistividade aparente (Figura 11), de teores de argila (Figuras 12 e 13) e o de solos (Figura 2), denotando a importância da geofísica como ferramenta auxiliar na cartografia pedológica.

\section{Difratometria de raios $\mathrm{X}$ dos solos}

Foram realizadas seis análises por difratrometria de raios $\mathrm{X}$ em amostras compostas para as profundidades de $0-20$ e 20 $40 \mathrm{~cm}$, sendo duas para cada um dos três tipos de solos.

As Figuras 16 a 19 referem-se aos difratogramas dos solos argilosos (Nitossolo Vermelho Eutrófico e Latossolo VermeIho Eutroférrico), oriundos da decomposição de rochas eruptivas básicas. A constituição mineralógica de tais solos mostrou-se bastante uniforme, onde foram identificados os seguintes minerais: montmorilonita, caulinita, quartzo, goetita e hematita.

Os difratogramas mostram as formas de tratamento das amostras, objetivando a identificação dos minerais. Primeiramente procurou-se identificá-los in natura, seguido do aquecimento em mufla a $550^{\circ} \mathrm{C}$, e, posteriormente, pelo tratamento com etilenoglicol.

Os picos da montmorilonita (grupo das esmectitas), identificados pelo espaçamento de $13,7 \AA$, mineral de argila de grade 2:1, possui duas lâminas de sílica tetraédrica laterais e uma de alumina octaédrica central, e apresenta alta expansibilidade. Isto torna possível um grande número de substituições isomórficas de cátions (K, Na, Ca, etc.), por apresentar alta CTC (80 a $120 \mathrm{cmol}_{\mathrm{c}}$ $\left.\mathrm{Kg}^{-1}\right)$ e grande área de superfície específica $\left(800 \mathrm{~m}^{2} \mathrm{~g}^{-1}\right)$. Os radionuclídeos, por possuírem cargas positivas, podem ficar adsorvidos nas cargas negativas destes minerais, principalmente 0 urânio, cuja concentração se mostrou maior nestes solos, com teores de argila ultrapassando 70\% (Tabela 8). 


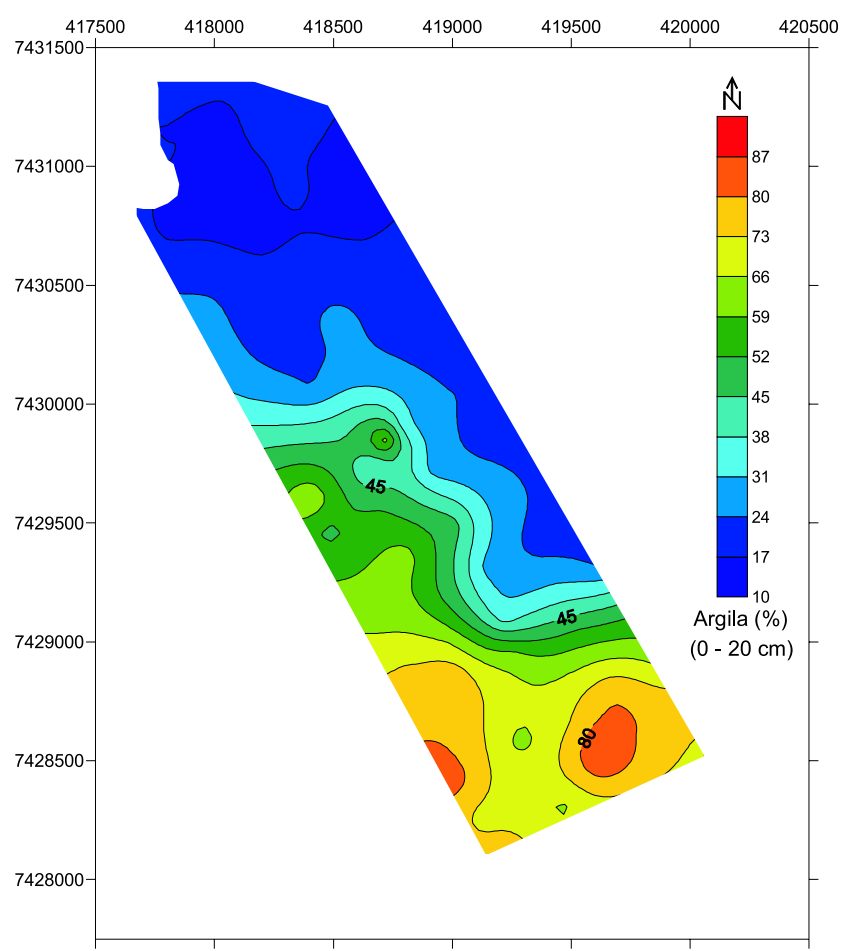

Figura 12 - Distribuiç̧ão espacial da argila para a profundidade $0-20 \mathrm{~cm}$.

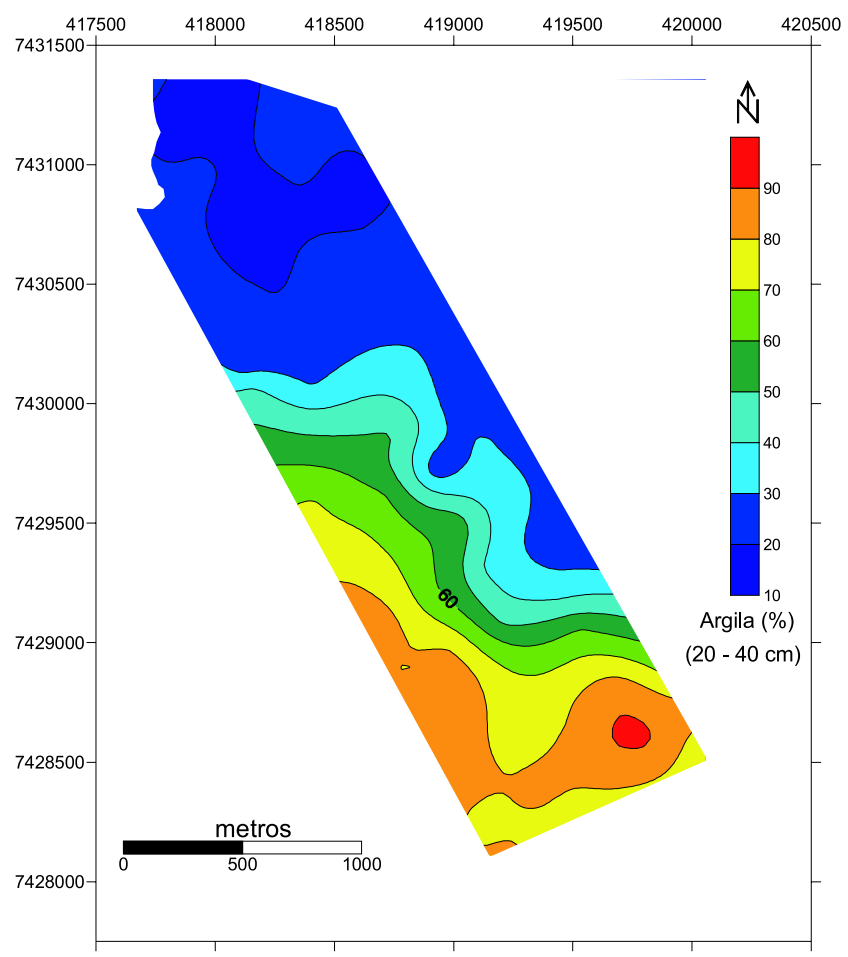

Figura 13 - Distribuição espacial da argila para a profundidade 20 - $40 \mathrm{~cm}$. 


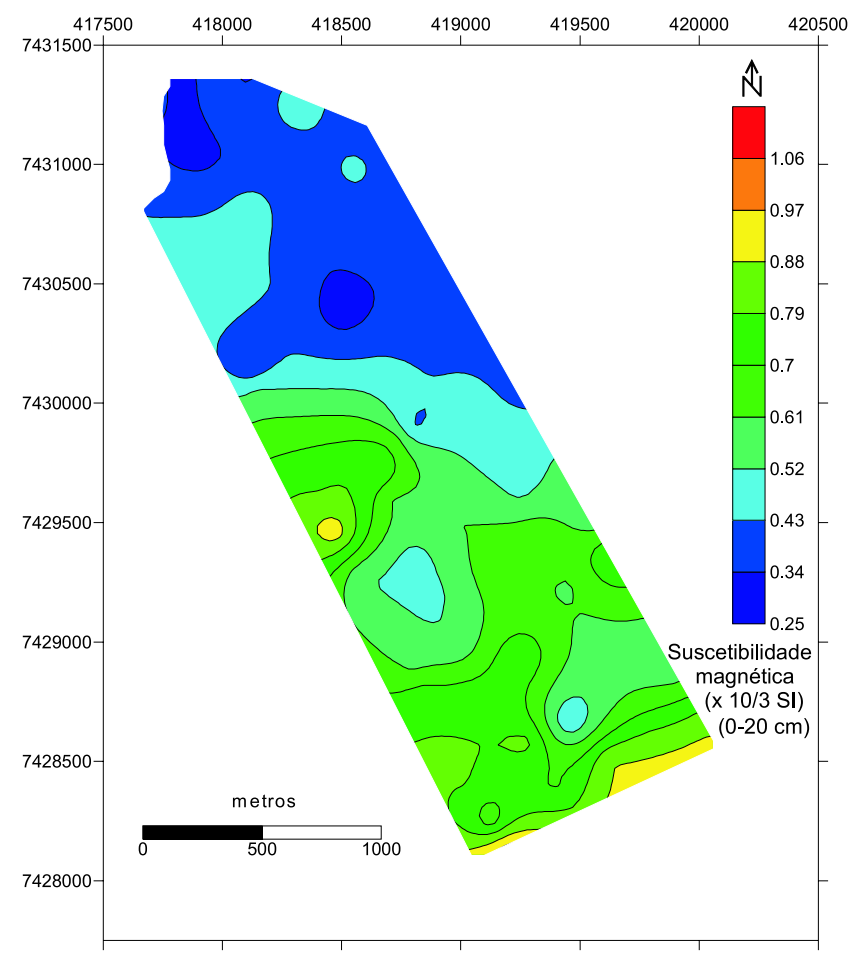

Figura 14 - Susceptibilidade magnética dos solos para a profundidade $0-20 \mathrm{~cm}$.

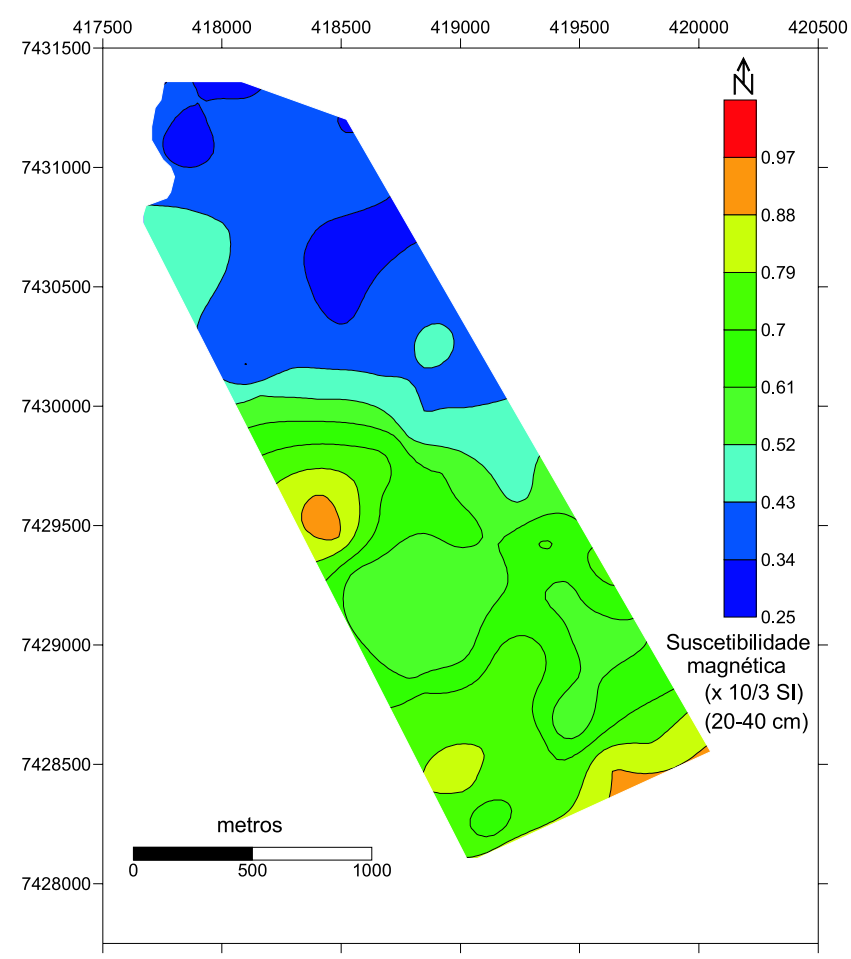

Figura 15 - Suscetibilidade magnética dos solos para a profundidade $20-40 \mathrm{~cm}$. 


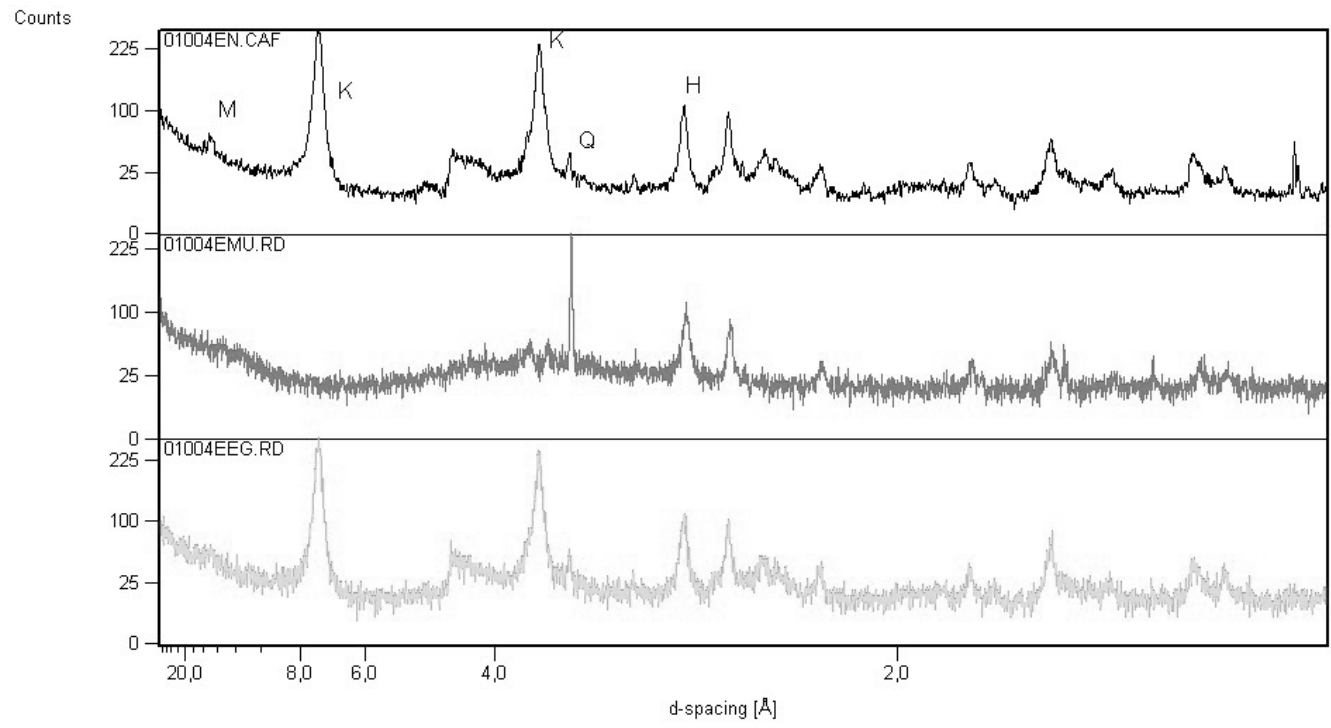

Figura 16 - Difratogramas comparativos de raios X obtidos com diferentes tratamentos (amostra 1/0-20 cm - Nitossolo Vermelho Eutrófico). De cima para baixo: amostra in natura, aquecida em mufla a $550^{\circ} \mathrm{C}$ e tratada com etilenoglicol ( $\mathrm{M}=$ montmorilonita; $\mathrm{K}=$ caulinita; $\mathrm{H}=$ hematita; $\mathrm{Q}=$ quartzo).

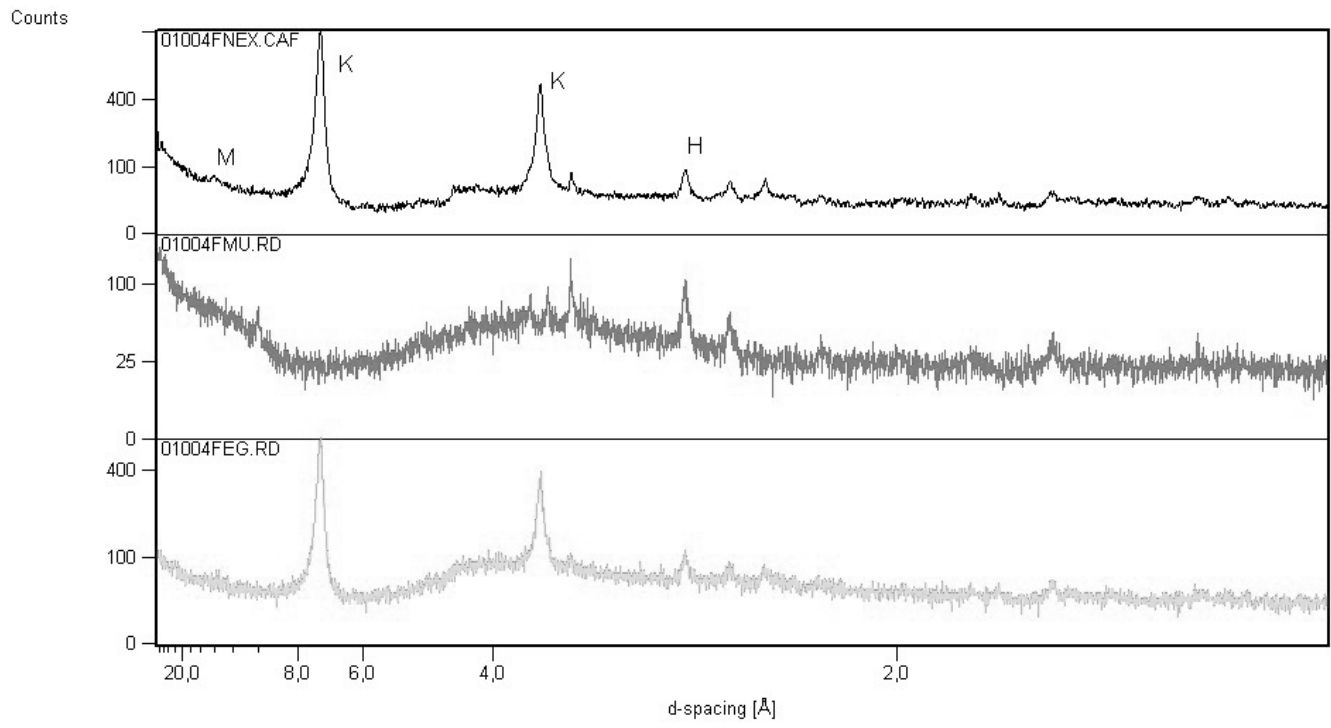

Figura 17 - Difratogramas comparativos de raios $X$ obtidos com diferentes tratamentos (amostra 2/20-40 cm - Nitossolo Vermelho Eutrófico). De cima para baixo: amostra in natura, aquecida em mufla a $550^{\circ} \mathrm{C}$ e tratada com etilenoglicol $(\mathrm{M}=$ montmorilonita; $\mathrm{K}=$ caulinita; $\mathrm{H}=$ hematita).

É plausível que os radionuclídeos não fiquem apenas adsorvidos nos bordos do referido mineral de argila, mas também podem fazer parte das substituições isomórficas, cujos cátions são retidos no solo, na seguinte ordem: $\mathrm{Ca}^{+2}>\mathrm{Mg}^{+2}>\mathrm{K}^{+}>\mathrm{Na}^{+}$, denominada série liotrópica (Raij, 1983).

0 fator determinante para a atração é a carga dos cátions, seguido do tamanho dos íons hidratados (raio iônico), sendo os menores retidos com maior energia (Malavolta, 1976; Raij, 1983). Em função de seu potencial iônico mais elevado no ambiente subsuperficial rico em oxigênio, $0 \mathrm{U}^{+4}$ oxida-se pela perda de elétrons, passando ao estado de $\mathrm{U}^{+6}$, enquanto $0 \mathrm{Th}^{+4}$ permanece no perfil devido à sua configuração eletrônica (Rebello, 


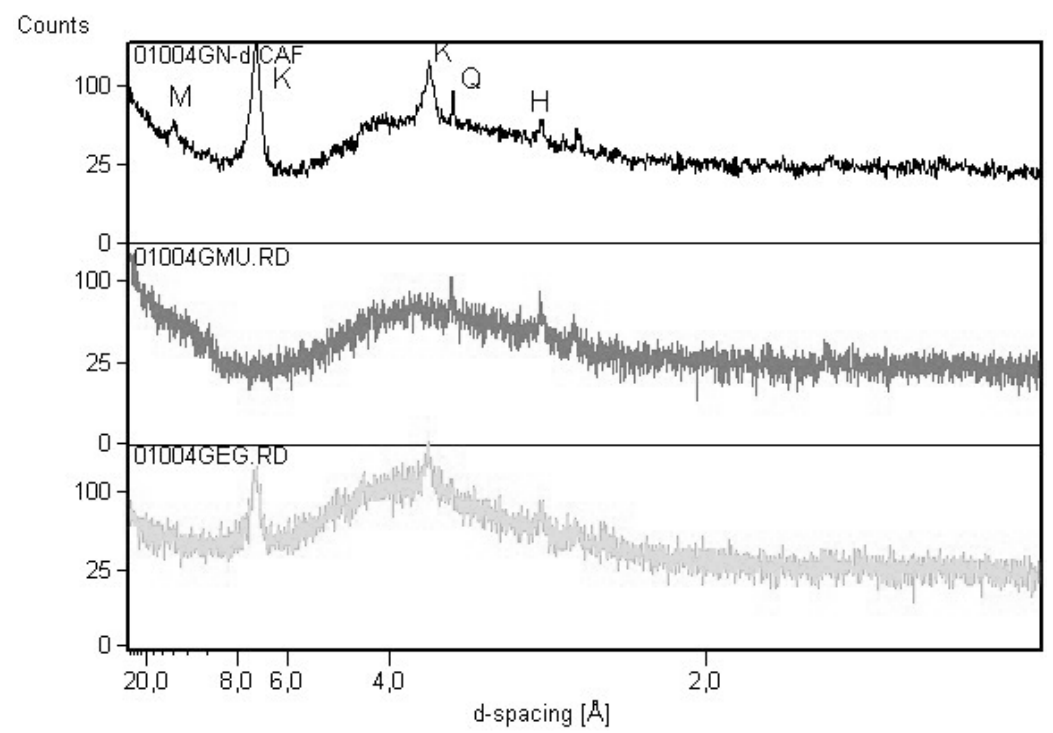

Figura 18 - Difratogramas comparativos de raios $X$ obtidos com diferentes tratamentos (amostra 1/0-20 $\mathrm{cm}$ - Latossolo Vermelho Eutroférrico). De cima para baixo: amostra in natura, aquecida em mufla a $550^{\circ} \mathrm{C}$ e tratada com etilenoglicol ( $\mathrm{M}$ = montmorilonita; $\mathrm{K}=$ caulinita; $\mathrm{H}=$ hematita; $\mathrm{Q}=$ quartzo).

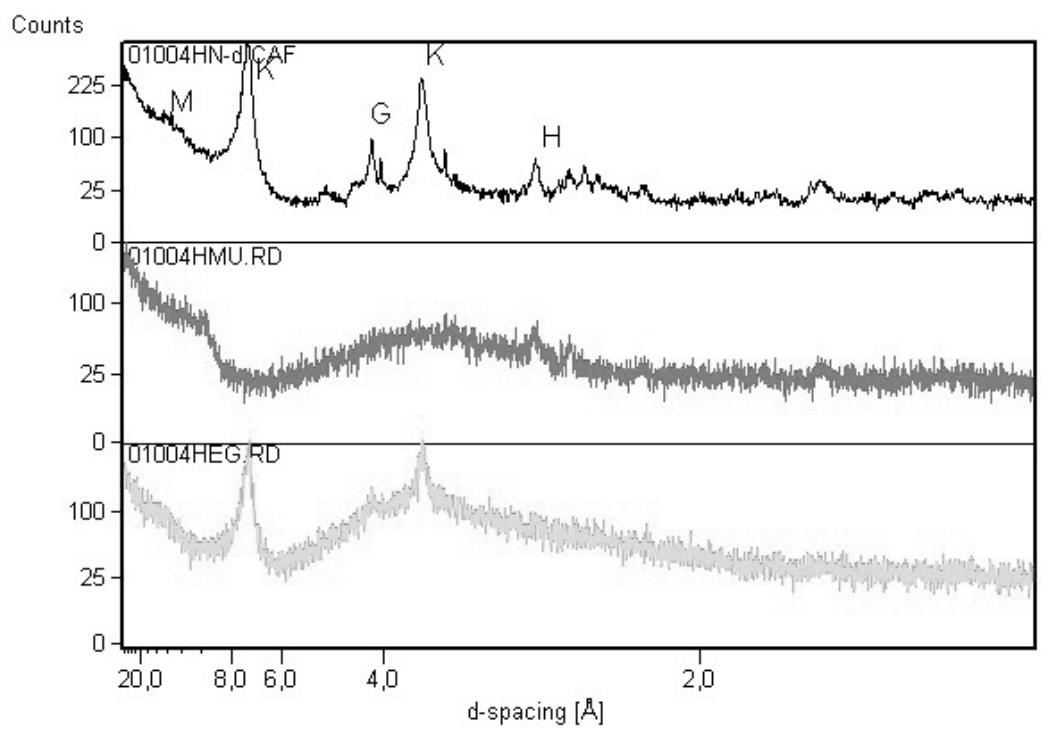

Figura 19 - Difratogramas comparativos de raios X obtidos com diferentes tratamentos (amostra 2/20-40 $\mathrm{cm}$ - Latossolo Vermelho Eutroférrico). De cima para baixo: amostra in natura, aquecida em mufla a $550^{\circ} \mathrm{C}$ e tratada com etilenoglicol ( $\mathrm{M}=$ montmorilonita; $\mathrm{K}$ = caulinita; $\mathrm{H}=$ hematita; $\mathrm{G}=$ goetita).

2000). 0 raio iônico do U $(0,95 \AA)$, do Th $(0,98 \AA)$ e do $K(1,33 \AA)$, são comparáveis aos do $\mathrm{Ca}^{+2}(0,99 \AA)$ e do $\mathrm{Na}^{+1}(0,97 \AA)$. Assim, principalmente $0 \mathrm{U}^{+6}$, apresenta todas as condições de competitividade por sítios de trocas com $0 \mathrm{Ca}^{+2}$ e $0 \mathrm{Na}^{+1}$ na superfície dos minerais de argila, bem como na substituição isomórfica da rede cristalina naqueles expansíveis, como a montmorilonita. A
Tabela 16 indica as características de alguns elementos químicos e a ordem preferencial de adsorção química nos solos.

Decorrente do intemperismo químico intenso, as argilas, como a montmorilonita, se transformam em caolinita nos solos mais velhos e altamente lixiviados, os quais possuem menor poder de adsorção de íons metálicos (Borovec, 1981), cuja 
presença foi detectada em todos os difratogramas. Fica evidenciado que ao se aquecer as amostras à $550^{\circ} \mathrm{C}$, a caolinita desaparece em função da destruição de suas estruturas cristalinas (Moraes, 1992; Almeida et al., 1997). Mesmo com menor capacidade de retenção de cátions, ela contribui com cargas negativas para a adsorção dos mesmos, embora não seja expansível, praticamente impedindo a substituição de cátions na rede cristalográfica. A presença de caolinita nos solos estudados pode ser atribuída ao intenso intemperismo e à decomposição de alguns minerais primários resultantes de condições físicoquímicas adequadas para a formação do referido mineral de argila (Souza, 1973; Galhego \& Espíndola, 1979).

Tabela 16 - Características de alguns elementos químicos e ordem preferencial de adsorção química nos solos.

\begin{tabular}{|c|c|c|c|}
\hline Elementos & Raio iônico $(\AA)$ & Valência & Ordem preferencial \\
\hline Urânio & 0,95 & +6 & 1 \\
\hline Tório & 0,98 & +4 & 2 \\
\hline Alumínio & 0,51 & +3 & 3 \\
\hline Magnésio & 0,66 & +2 & 4 \\
\hline Cálcio & 0,99 & +2 & 5 \\
\hline Lítio & 0,83 & +1 & 6 \\
\hline Sódio & 0,97 & +1 & 7 \\
\hline Potássio & 1,33 & +1 & 8 \\
\hline
\end{tabular}

Fonte: Adaptado de Raij (1983).

Quanto há ocorrência de formas de ferro, observa-se a presença de hematita em todos os difratogramas de raios $X$, cuja explicação é dada pelo material de origem dos solos (basaltos, ricos em minerais ferromagnesianos). Os óxidos de ferro imprimem aos solos uma coloração vermelha e 0 incremento de seus teores acarreta uma cor vermelha escura, pelo que são facilmente identificados no campo.

Os óxidos e hidróxidos de ferro (hematita e goetita), em solos tropicais, também podem contribuir para a fixação de elementos radiogênicos. A incorporação de metais nas fases de óxidos de ferro é observada para uma grande variedade de metais de transição (Ford et al., 1997; Martinez \& McBride, 1998). Não se acredita que 0 urânio seja incorporado na estrutura $\alpha-\mathrm{FeOOH}$ da goetita (Gerth, 1990). Contudo, há pouca informação a respeito da incorporaçãa estrutural de $\mathrm{U}$ em óxidos de Fe, ou sobre a quantidade de $\mathrm{U}$ que pode ser retida nas fases hospedeiras daqueles óxidos que ocorrem naturalmente. A retenção de U nos perfis dos solos oriundos de rochas profundamente alteradas, deve-se à estabilidade das fases acessórias contendo $\mathrm{U}$, e ao $\mathrm{U}$ adsorvido pelos produtos do intemperismo, como argilas e óxidos de Fe e Mn.
Portanto, os compostos de U solúvel são fortemente adsorvidos pelos hidróxidos de Fe, Al e Mn.

0 Th livre pode ser retido, sobretudo em óxidos e hidróxidos de Fe e Al. No entanto, assim como o U, o Th também pode ser transportado em solução coloidal, adsorvido em argilas e óxidos de Fe (Dickson \& Scott, 1997) e colóides orgânicos (Viers et al., 1997). Durante o retrabalhamento das anomalias associadas aos Latossolos, conforme Tieh et al. (1980), a redistribuiçã̃o de resistatos contendo Th e $\mathrm{U}$, bem como a maior parte dos minerais e fases coloidais contendo Th, pode ser afetada pelos processos pedogenéticos de eluviação-iluviação.

As Figuras 20 e 21 mostram a constituição mineralógica do Latossolo Vermelho Distrófico, textura mista. Assim como nos difratogramas anteriores, nota-se a presença da montmorilonita, cuja presença neste solo pode ser explicada pelo fato do mesmo ter sua origem no material retrabalhado das formações Serra Geral, principalmente, e Goio-Erê. A grande predominância é de quartzo, sendo que o teor médio de argila é de 25,2\% (Tabela 7).

Como a composição destes solos é predominantemente arenosa, derivada da Formação Goio-Erê, os teores de potássio são maiores, comparativamente aos solos argilosos, tanto nos tratos sob floresta nativa (Tabela 9), quanto na área com atividade antrópica. É provável que a maior concentração do potássio esteja relacionada a mineralogia destes solos. De fato, o microclínio é 0 feldspato potássico preodominante no cimento dos arenitos do Grupo Cauiá (Fernandes \& Coimbra, 2000). Este fato explica, ao menos em parte, a baixa relação $\mathrm{Na} / \mathrm{K}$ nas águas superficiais e/ou subterrâneas do mencionado Grupo (Bittencourt, 1982; Bettú et al., 2005).

\section{Teores de matéria orgânica dos solos}

Os teores de matéria orgânica por tipo de solo, considerando-se a percentagem de argila para as duas profundidades, encontram-se na Tabela 17 e as suas distribuições espaciais respectivas podem ser vistas nas Figuras 22 e 23. Os solos argilosos apresentam teores mais elevados $(3,11$ e 2,69\%) do que 0 areno-argiloso $(1,43$ e 1,11\%), respectivamente. A matéria orgânica de tais solos é oriunda do sistema de manejo utilizado, denominado plantio direto, onde a resteva das culturas da soja e do trigo não são queimadas, permanecendo sobre a superfície dos solos, não sendo removidas por processos de aração e gradagem, formando uma "manta" que protege os mesmos de processos erosivos mais intensos. Neste caso, a matéria orgânica vai sendo decomposta paulatinamente pela fauna edáfica.

Os solos argilosos, por possuírem minerais de argila com 


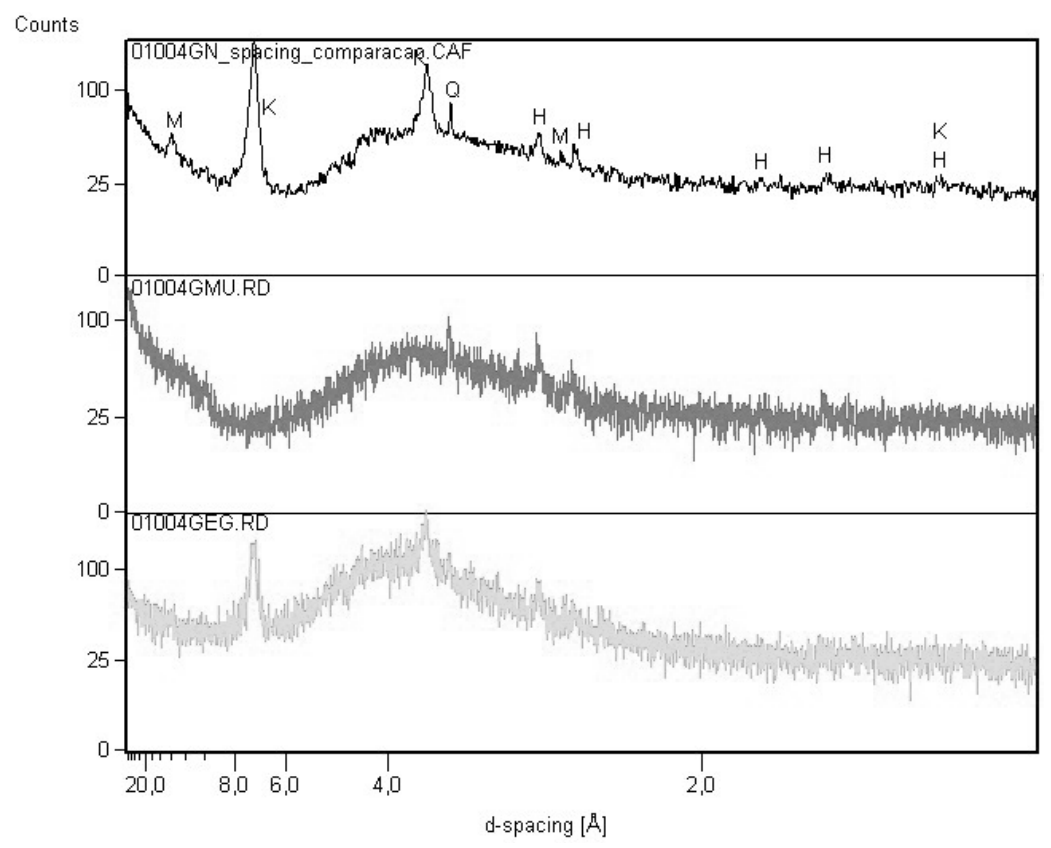

Figura 20 - Difratogramas comparativos de raios $X$ obtidos com diferentes tratamentos (amostra 1/0-20 cm - Latossolo Vermelho Distrófico). De cima para baixo: amostra in natura, aquecida em mufla a $550^{\circ} \mathrm{C}$ e tratada com etilenoglicol ( $\mathrm{M}$ = montmorilonita; $\mathrm{K}=$ caulinita; $\mathrm{H}=$ hematita $\mathrm{e} \mathrm{Q}=$ quartzo).

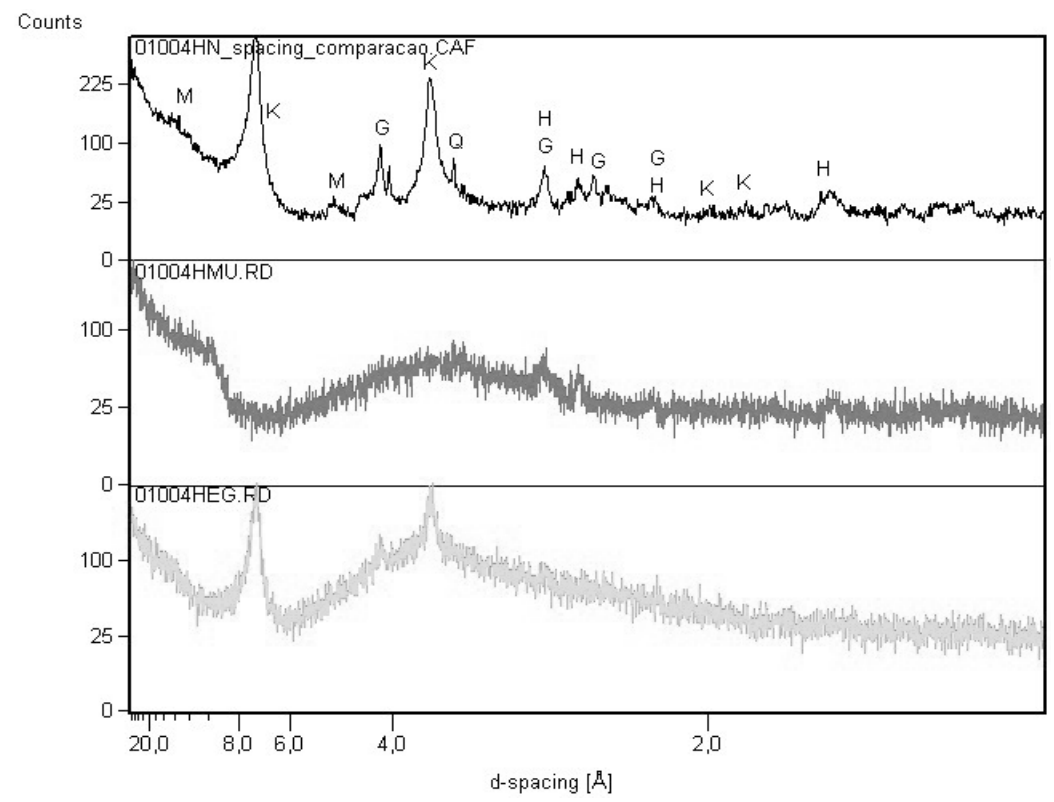

Figura 21 - Difratogramas comparativos de raios $X$ obtidos com diferentes tratamentos (amostra 2/0-20 $\mathrm{cm}$ - Latossolo Vermelho Distrófico). De cima para baixo: amostra in natura, aquecida em mufla a $550^{\circ} \mathrm{C}$ e tratada com etilenoglicol ( $\mathrm{M}$ = montmorilonita; $\mathrm{K}$ = caulinita; $\mathrm{H}$ = hematita; $\mathrm{G}=\mathrm{Goetita;} \mathrm{Q}$ = quartzo). 


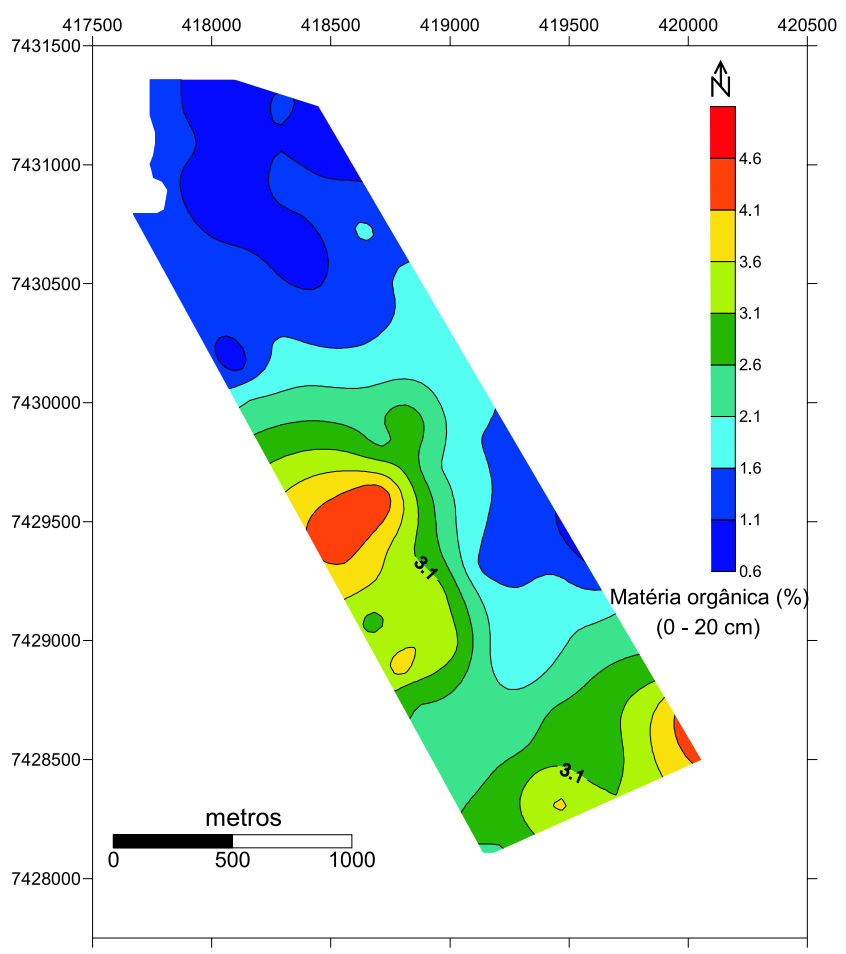

Figura 22 - Distribuição espacial da matéria orgânica para a profundidade $0-20 \mathrm{~cm}$.

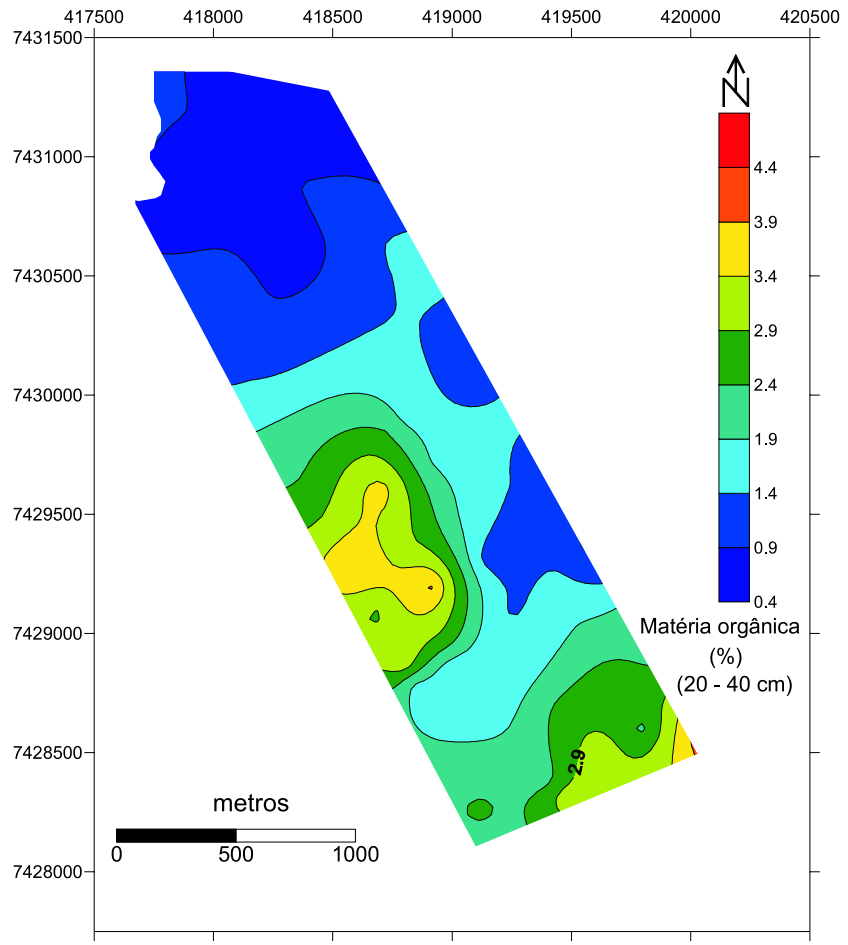

Figura 23 - Distribuição espacial da matéria orgânica para a profundidade 20 - $40 \mathrm{~cm}$. 
Tabela 17 - Estatísticas dos teores de matéria orgânica por tipo de solo para as duas profundidades.

\begin{tabular}{|c|c|c|c|c|}
\hline \multirow{2}{*}{} & Areno/argiloso & Argilosos & Areno/argiloso & Argilosos \\
\cline { 2 - 5 } & \multicolumn{4}{|c|}{ Profundidades (cm) } \\
\cline { 2 - 5 } & $0-20$ & $0-20$ & $20-40$ & $20-40$ \\
\hline Mínimo & 0,60 & 1,60 & 0,50 & 1,40 \\
\hline Máximo & 3,40 & 4,60 & 2,10 & 4,30 \\
\hline Média & $\mathbf{1 , 4 3 a}$ & $\mathbf{3 , 1 1 b}$ & $\mathbf{1 , 1 1 a}$ & $\mathbf{2 , 6 9 c}$ \\
\hline Desvio padrão & 0,57 & 0,79 & 0,39 & 0,74 \\
\hline Coeficiente de variação (\%) & 39,90 & 25,48 & 35,13 & 27,51 \\
\hline Assimetria & 3,14 & $-0,73$ & $-0,43$ & $-0,38$ \\
\hline Curtose & 1,39 & 0,30 & 0,30 & 0,37 \\
\hline
\end{tabular}

Médias seguidas de letras iguais na linha não diferem significativamente a $5 \%$ pelo teste t.

grade 2:1 (montmorilonita), contribuem para aumentar a CTC, diferentemente daqueles cuja textura areno-argilosa possui CTC menor, onde predominam quartzo e caolinita, como já referido. Assim sendo, os teores de matéria orgânica contribuem decisivamente para a capacidade de troca catiônica dos referidos solos.

Os teores de urânio nos solos argilosos foram significativamente maiores do que no solo areno-argiloso (Tabela 9). Este contraste não está relacionado apenas aos diferentes teores de argila, mas também à contribuição da matéria orgânica, a qual tem grande importância na retenção de íons, principalmente U. É interessante notar que as correlações positivas entre urânio e matéria orgânica, para as duas profundidades (0-20 e 20-40 cm), foi a mesma $(r=0,92)$ e bem mais elevada do que entre argila e urânio para os citados níveis ( $r=0,50$ e 0,56, respectivamente), em função da maior capacidade da matéria orgânica em reter radionuclídeos e outros íons.

0 adubo para culturas anuais como a soja e o trigo é depositado nos cinco primeiros centímetros de profundidade do solo, próximo das sementes. No processo de dissolução dos grânulos dos adubos acidulados, a dinâmica do íon urânio é regida por vários mecanismos, podendo formar complexos solúveis com os carbonatos, oxalatos e hidróxidos (Grenthe et al., 1992). Na ausência de altos níveis de complexos de ligação, o U dissolvido se liga aos minerais de óxidos e hidróxidos de ferro como a hematita, a goetita, além de alumínio e matéria orgânica em diversas faixas de pH (Waite et al., 1994; Moyses et al., 2000).

Existe uma relação clara entre abundância dos elementos e seus coeficientes de migração. Assim como o conceito de abundância, o de migração, ou mobilidade de elementos, pode ser discutido em termos absolutos e relativos. Nos estudos de campo, como no presente caso, deve-se levar em consideração a mobilidade dos radionuclídeos sob esses dois aspectos, uma vez que existem diferentes taxas de migração quando um mesmo elemento ocorre em diferentes espécies químicas. Fatores como a dinâmica da água (precipitação), o relevo, os tipos de solos e os regimes hídricos, juntamente com as características físicoquímicas do solo, ditam a dinâmica dos elementos geoquímicos no perfil do solo.

\section{CONCLUSÕES}

As principais conclusões da pesquisa podem ser sumarizadas como segue: (i) os solos Nitossolo Vermelho Eutrófico e Latossolo Vermelho Eutroférrico de textura argilosa, retém mais radionuclídeos do que o Latossolo Vermelho Distrófico textura mista; (ii) os teores de radionuclídeos são mais baixos em área de floresta nativa, quando comparados com os tratos de atividade agrícola, denotando a contribuição dos fertilizantes fosfatados e do gesso no incremento dos teores nos solos cultivados; (iii) foram constatadas diferenças nos teores de radionuclídeos, em correspondência às formulações dos adubos, as quais se refletiram nas medidas gamaespectrométricas; (iv) houve correlação positiva e significativa entre urânio e argila, urânio e matéria orgânica, argila e susceptibilidade magnética e negativa entre argila e resistividade elétrica; (v) finalmente, os métodos geofísicos empregados se revelaram ferramentas auxiliares importantes na cartografia pedológica.

\section{AGRADECIMENTOS}

Os autores agradecem a Universidade do Estado de Santa Catarina (UDESC) pela licença concedida para capacitação; a CAPES pela concessão de bolsa PICDT, cujo trabalho faz parte da Tese de Doutoramento do primeiro autor no Curso de PósGraduação em Geologia Ambiental da Universidade Federal do Paraná (UFPR); ao Laboratório de Minerais e Rochas (LAMIR), 
Departamento de Geologia da UFPR, pelas difratometrias de raios X; ao professor Jean Marie Flexor (ON-MCT) pela valiosa colaboração na calibração do gamaespectrômetro; aos professores Augusto César Bittencourt Pires e Carlos Tadeu CarvaIho do Nascimento (LGA-UnB), respectivamente pelo empréstimo do resistivímetro e pela valiosa colaboração na aquisição dos dados geoelétricos.

\section{REFERÊNCIAS}

AGUIRRE AM, LÉON MG \& IVANOVICH M. 1995. U and Th speciation in river sediments. The Science of the Total Environment, 173/174: 203-209.

ALMEIDA JA, KÄMPF N \& ALMEIDA R. 1997. Caracterização mineralógica de cambissolos originados de rochas pelíticas nos patamares do alto rio Itajaí e no planalto de Lages (SC). Revista brasileira de Ciência do Solo, Campinas, 21: 181-190

ARYA AP. 1966. Fundamentals of Nuclear Physics. Boston: Allyn and Bacon Inc.

BANTON 0, SEGUIN MK \& CLIMON MA. 1997. Mapping field scale physical properties of soil with electrical resistivity. Soil Science Society of Journal, 61: 1010-1017.

BARRETTO PMC, AUSTERLITZ C, MALHEIROS T \& LOVBORG L. 1986. Radioactive concrete sources at IRD/CNEN, Brazil, for the calibration of uranium exploration and environmental field instruments. Relatório IRD/DEX-3/CNEN, 66

BAYER C \& MIELNICZUK J. 1997. Características químicas do solo afetadas por métodos de preparo e sistemas de cultura. Revista brasileira de Ciência do Solo, 21: 105-112.

BETTÚ DF, FERREIRA FJF, SALAMUNI E \& FERNANDES LA. 2005. Conectvidade e compartimentação dos sistemas aqüíferos Caiuá e Serra Geral no noroeste do estado do Paraná. In: X Simpósio Nacional de Estudos Tectônicos e IV International Symposium on Tectonics, Sociedade Brasileira de Geologia, Núcleo Paraná, Boletim de Resumos Expandidos, p. 253-257.

BITTENCOURT AVL. 1978. Sólidos hidro transportados na bacia hidrográfica do Rio Ivaí: aplicação de balanços hidrogeoquímicos na compreensão da evolução de processos da dinâmica externa. São Paulo, 201p. (Tese de Doutorado - Universidade de São Paulo).

BITTENCOURT AVL. 1982. Transporte de sólidos na bacia hidrográfica do Rio Ivaí. Boletim Paranaense de Geociências n. 35: 1-54.

BOLIVAR JP, TENÓRIO RG \& LÉON G. 1995. Fluxes and distribution of natural radionuclides in the production and use of fertilizers. Appl. Radiat. Isot. 46(6/7): 717-718.

BOROVEC Z. 1981. The adsorption of uranyl species by fine clay. Chemical Geology, 32: 45-58.
BRADY NC. 1979. Natureza e propriedades dos solos. p. 647, $5^{\mathrm{a}}$ ed. Rio de Janeiro.

CELI M, SCHNITZER M \& NÉGRE M. 1997. Analysis of carboxyl groups in soil humic acid by a wet chemical method, fourier-transform infrared spectrophometry, and solution-state carbon-13 nuclear magnetic resonance. A comparative study. Soil Science, Baltimore, 162: 189-196.

CORWIN DL \& RHOADES JD. 1984. Measurement of inverted electrical conductivity profiles using electromagnetic induction. Soil Science Society of America Journal, 48: 288-291.

CURI N. 1975. Relações genéticas e geomórficas em solos das encostas inferior e superior do Nordeste no Rio Grande do Sul. Porto Alegre. 134 p. (Dissertação de Mestrado em Agronomia - Universidade Federal do Rio Grande do Sul).

DICKSON BL \& SCOTT KM. 1997. Interpretation of aerial gamma-ray surveys - adding the geochemical factors. AGSO Journal of Australian Geology \& Geophysics, Australia, 17(2): 187-200.

DOWDALL M \& O'DEA J. 2002. ${ }^{226} \mathrm{Ra}$ /238 $\mathrm{U}$ disequilibrium in an upland organic soil exhibiting elevated natural radioactivity. Journal of Environmental Radioactivity, 59: 91-104.

EMBRAPA SNLCS. 1984. Levantamento de reconhecimento dos solos do Estado do Paraná. Curitiba, 413 p. (Boletim Técnico, 57).

FERNANDES LA \& COIMBRA AM. 2000. Revisão estratigráfica da parte oriental da bacia Bauru (Neocretáceo). Revista Brasileira de Geociências 30(4): 723-734.

FERREIRA FJF, SOUZA JL, ROCHA HO \& MANTOVANI LE. 1997. Airborne gamma-ray spectrometry and remote sensing to map uranium accumulation in soils from long continued application of fertilizers in Araras region, Brazil. In: $12^{\text {th }}$ International Conference and Workshops, Applied Geologic Remote Sensing, Denver, Colorado, USA. V.I, p. 323-330

FERREIRA FJF, FLEXOR JM \& GUIMARÃES GB. 2003. Síntese da calibração do gamaespectrômetro GS-512 do LPA/UFPT no IRD-CNEN 12 p. (relatório inédito).

FORD RG, BERSTSCH PM \& FARLEY KJ. 1997. Changes in transition and heavy metal partitioning during hydrous iron oxide aging. Environ. Sci. Technol, 31: 2028-2033.

GALHEGO HR \& ESPÍNDOLA CR. 1979. Mineralogia da argila de solos desenvolvidos de produtos de alteração de rochas eruptivas básicas em Botucatu (SP). Revista brasileira de Ciência Solo. 3: 131-135.

GEOFYZIKA. 1998. Portable Gamma-Ray Spectrometer (GS-512), Instruction Manual, Brno Version 2.00, Czech Republic, 77 p.

GERTH J. 1990. Unit-cell dimensions of pure and trace metal-associated goethites. Geochimica Cosmochimica Acta, 64: 363-371.

GIANNINI PCF \& RICCOMINI C. 2001. In: Decifrando a Terra. São Paulo: Oficina de textos. $568 \mathrm{p}$. 
GIMENEZ AF, PIRES NETO AG \& RICOMINI C. 1983. Mapeamento geológico do bloco SF-22T (ACS-33). São Paulo: Instituto de Pesquisas Tecnológicas, 1983, 69 p. (relatório 14845).

GRENTHE I, FUGER J, KONINGS R, LEMIRE RJ, MULLER AB \& WANNER J. 1992. The Chemical thermodynamics of uranium. Elsevier.

GUIMOND RJ \& HARDIN JM. 1989. Radioactivity released from phosphate-containing fertilizers and from gypsum. J. Radiat. Appl. Instrum. Radiat. Phys. Chem., 34(2): 309-315.

GUIMOND RJ. 1978. The Radiological aspects of fertilizer utilization. Radioactivity in Consumer Products, US Nuclear Regulatory Commission, Washington, p. 380-392.

GUNN RH. 1974. A soil catena on weathered basalt in Queensland, Aust. J. Soil Res., 12: 1-14.

IAPAR. Instituto Ambiental do Paraná. 1978. Cartas climáticas básicas do Estado do Paraná. Londrina, 41 p.

KANNAN V, RAJAN MP, IYENGAR MAAR \& RAMESH R. 2002. Distribution of natural and anthropogenic radionuclides in soil and beach samples of Kalpakkam (India) using hyper pure germanium (HPGe) gamma ray spectrometry. Appl. Radiat. Isot. 57: 109-119.

KAMPF N \& KLAMT E. 1978. Mineralogia e gênese de Latossolos (Oxisols) e solos Podzólicos da região nordeste do Planalto SulRiograndense. Revista brasileira de Ciência do Solo, 2: 68-73.

KHAN K, KHAN HM, TUFAIL M, KHATIBEH AJAH \& AHMAD N. 1998. Radiometric Analysis of Hazara Phosphate Rock and Fertilizers in Pakistan. J. of Environ. Radioactivity, 38(1): 77-84.

KOEFOED 0. 1979. Resistivity Sounding Measurements. Elsevier, Amsterdan, $276 \mathrm{pp}$.

KUMRU MN \& BAKAÇ M. 2003. R-mode factor analysis applied to the distribution of elements in soils from the Aydin basin, Turkey. J. of Geoch. Exploration 77: 81-91.

McBRIDE RA, GORDON AM \& SHRIVE SC. 1990. Estimating forest soil quality from terrain measurements of apparent electrical conductivity. Soil Science Society of America Journal, 54: 290-293.

MALAVOLTA E. 1976. Manual de Química Agrícola. Ed. Ceres Ltda. São Paulo. $528 \mathrm{p}$.

MARQUES LS. 1988. Rare elements. In: PICCIRILO EM \& MELFI AJ. The Mesozoic flood volcanism of the Paraná Basin. São Paulo: Universidade de São Paulo, Instituto Astronômico e Geofísico. p. 499-504.

MARTINEZ CE \& McBRIDE MB. 1998. Co-precipitates of Cd, Cu, Pb and $\mathrm{Zn}$ in iron oxides: Solid phase transformations and metal solubility after aging and thermal treatment. Clays and Clay Minerals, 46: 537-545.

MAZZILLI B, PALMIRO V, SAUEIA C \& NISTI MB. 2000. Radiochemical characterization of Brazilian phosphogypsum. J. of Environ. Radioactivity, 49: 113-122.
MORAES MH. 1992. Discriminação de horizontes e de unidades-de-solo e sua ordenação numa toposseqüência proveniente de rochas eruptivas básicas. Piracicaba, 153 p. (Tese de Doutorado - Esalq/USP).

MOYSES LN, PARKMAN RH, CHARNOCK DJ, LIVENS FT, HUGHES CR \& BRAITHWAITE A. 2000. Uranium uptake from aqueous solution by interation with goethite, lepidocrocite, muscovite and mackinawite: An x-ray absorption spectroscopy study. Environ. Sci. Technol, 34: 1062-1068.

NADLER A \& FRENKEL H. 1980. Determination of soil solution electrical conductivity from bulk soil electrical conductivity measurements by the four electrode method. Soil Science Society of America Journal, 44: 1216-1221.

NASCIMENTO CTC. 2003. Resistividade elétrica e radiação gama natural no estudo de solos sob cerrado nativo. Tese de Doutoramento, Universidade de Brasília, $111 \mathrm{p}$.

NASCIMENTO CTC, PIRES ACB \& MORAES RAV de 2004. Reconhecimento de solos por meio de resistividade elétrica e radiação gama. Revista Brasileira de Geociências, 34(3): 383-392.

NASCIMENTO CTC do \& FERREIRA FJF. 2003. Relatório das medições gamaespectrométricas e de resistividade elétrica realizadas na área do projeto carbonatito. Relatório inédito. 28p.

NUERNBERG NJ, RECH TD \& BASSO C. 2002. Usos do gesso agrícola. Florianópolis: Epagri, 31p. Boletim Técnico, 122.

OGUNLEYEPO, MAYAKI MC \& AMAPU IY. 2002. Radioactivity and heavy metal composition of Nigerian phosphate rocks: possible environmental implications. Environmental Radioactivity, 62: 39-48.

PASCHOA AS, MAFRA OY, CARDOSO DO \& ROCHA ACS. 1984. Application of SSNTD to the Brazilian phosphate fertilizer industry to determine uranium concentrations. Nuclear Tracks and Radiation Measurements, 8(1-4): 469-472.

PFISTER H, PHILIPP G \& PAUL YH. 1976. Population dose from natural radionuclides in phosphate fertilizers Radiation and Environmental Biophysics, 13: 247-261.

PRADO H de. 2001. Solos do Brasil: gênese, morfologia, classificação e levantamento. 2.ed. revisada e ampliada. $220 \mathrm{p}$.

RAIJ BV. 1983. Avaliação da fertilidade do solo. Instituto da Potassa \& Fosfato.142 p.

REBELLO AMA de. 2000. Processos supergênicos na distribuição de radônio em paisagens tropicais úmidas. Curitiba. 209p. (Tese de Doutorado - Universidade Federal do Paraná).

RESENDE M, CURI N, RESENDE BS de \& CORRÊA GF. 1995. Pedologia: bases para distinção de ambientes. $304 \mathrm{p}$.

REYNOLDS JJ. 2003. An Introduction to Applied and Environmental Geophysics. 796 p. 
RIBEIRO FB, CARLOS DU, HIODO FY \& STROBINO EF. 2005. A Least squares procedure for calculating the calibration constants of a portable gamma-ray spectrometer. Radiation Protection Dosimetry, 113(3): 251256 .

RIGHI S, BETTI M, BRUZZI L \& MAZZOTTI G. 2000. Monitoring of natural radioactivity in working places. Microchemical Journal, 67: 119-126.

RING RJ. 1977. Recovery of by product uranium from the manufacture of fosfatic fertilizers. Atomic Energy, 12-20.

ROBAIN H, DESCLOITRES M, RITZ M \& ATANGANA QY. 1996. A multiscale electrical survey of a lateritic soil system in the rain forest of $\mathrm{Ca}$ meroon. Journal Appl. Geoph. 34: 237-253.

ROTHBAUM HP, McGAVESTON DA, WALL T, JOHNSTON AE \& MATTINGLY GEG. 1979. Uranium accumulation in soils from long-continued applications of superphosphate. Journal of Soil Science, 30(1): 147153

RUFINO RL, BISCAIA RCM \& MERTEN GH. 1993. Determinação do potencial erosivo da chuva do estado do Paraná, através de pluviometria: Terceira aproximação. Revista brasileira de Ciência do Solo, Campinas, 17: 439-444.

SAN AK, AHAMED MMO, EL KHANGI FA, EL NIGUMI YO \& HOLM E. 1999. Radiological and chemical assessment of Uro and Kurun rock phosphates. Environmental Radioactivity, 42: 65-75.

SAN MIGUEL PÉREZ-MORENO JP, BOLIIVAR JP \& GARCÍA-TENÓRIO R. 2003. Validation of isotope signatures in sediments affected by anthropogenic inputs from uranium series radionuclides. Environmental PolIution, 123: 125-130.

SAUEIA CH, MAZZILLI BP \& FÁVARO DIT. 2004. Natural radioactivity in phosphate rock, phosphogypsum and phosphate fertilizers in Brazil. Journal of Radioanalytical and Chemistry, 264(2): 445-448.

SHAINBERG I, RHOADES JD \& PRATHER RJ. 1980. Effect of exchangeable sodium percentage, cation exchange capacity, and soil solution concentration on soil electrical conductivity. Soil Science Society of America Journal, 44: 469-473.

SHERIFF RE. 1999. Encyclopedic Dictionary of Exploration Geophysics. Society of Exploration Geophysicists, Third Edition, 384 p.

SPALDING RF \& EXNER ME. 1976. Temporal uranium variations in the Brazos river. Radioecology and Energy Resources. p 230-233.

SROOR A, EL-BAHI SM, AHMED F \& ABDEL-HALEEM AS. 2001. Natural radioactivity and radon exhalation rate of soil in southern Egypt. Appl. Radiat. Isot. 55: 873-879.

SOUZA JLG. 1973. Estudo da fração argila da Terra Roxa Estruturada do Município de Botucatu para fins de gênese e classificação de solos. FCMBB, UNESP, Botucatu, 73 p. (Tese de Doutoramento).

SOUZA JL, FERREIRA FJF, ROCHA HO \& MANTOVANI LE. 1997. Soil radioactivity and its possible relationship with fertilizers in Araras region, Brazil. In: $4^{\text {th }}$ meeting on nuclear applications. Poços de Caldas: CNEN, 1997. CD-ROM.
SOUZA JL. 1998. Anomalias aerogamaespectrométricas (K, U e Th) da quadrícula de Araras (SP) e suas relações com processos pedogenéticos e fertilizantes fosfatados. Curitiba, Dissertação de Mestrado - Universidade Federal do Paraná.

TEDESCO JM, GIANELLO C, BISSANI CA, BOHNEN H \& VOLKWEISS SJ. 1995. Análises de solo, plantas e outros materiais. Porto Alegre: Departamento de solos. UFRGS. $174 \mathrm{p}$.

THENG BKG, TATE KR \& SOLLINS P. 1989. Constituents of organic matter in temperature and tropicals soils. In: COLEMAN DC et al. (Eds). Dynamics of soil organic matter in tropical ecosystems. Honolulu: NIPTAL Project, p. 5-32.

TIEH TT, LEDGER EB \& LIND B. 1980. Release of uranium from granitic rocks during in situ weathering and initial erosion (central Texas). Chemical Geology, 29: 227-248.

VELLOSO ACX, SANTOS GA \& RAMOS DP. 1982. Capacidade de troca de cátions e adsorção de fosfato de solos sob vegetação de Cerrado do Amapá. Pesquisa Agropecuária Brasileira, Brasília, 17: 27-32.

VIEIRA LS. 1975. Manual da ciência do solo. São Paulo. Ed. Agronômica Ceres, $464 \mathrm{p}$.

VIEIRA LS, SANTOS PCT \& VIEIRA MNF. 1988. Solos: propriedade, classificação e manejo. Brasília, MEC/ABEAS, 154 p.

VIERS J, DUPRÉ B, POLVÉ M, SCHOTT J, DANDURAND JL \& BRAUN JL. 1997. Chemical weathering in the drainage basin of a tropical watershed (Nsimi-Zoetele site, Cameroon): comparison between organic-poor and organic-rich waters. Chemical Geology, 140: 181-206.

WAITE TD, DAVIS JA, PAYNE TE, WAYCHUNAS GA \& Xu N. 1994. Uranium adsorption to ferrihydrite: Application of a surface complexation model. Geochim. Cosmochim. Acta, 58: 5465-5478.

WEIJDEN CH \& WEIJDEN RD. 1995. Mobility of major, minor and some redox-sensitive trace elements and rare-earth elements during weathering of four granitoids in central Portugal. Chemical Geology, 125: 149167.

WILFORD JR, BIERWIRTH PN \& CRAIG MA. 1997. Application of airborne gamma-ray spectrometry in soil/regolith mapping applied geomorphology. AGSO. J. Austral. Geol. Geophy., 17: 201-216.

YAMAZAKI IM \& GERALDO LP. 2003. Uranium content in phosphate fertilizers commercially produced in Brazil. Appl. Radiat. Isot. 59: 133136.

ZIELINSKI RA, BOLINDER SA, MÉIER AL, JONHSON CA \& SZABO BJ. 1997. Natural or fertilizer-derived uranium in irrigation drainage: a case study in southeastern Colorado, USA. Applied Geochemistry, 12: 9-21.

ZIELINSKI RA, SIMMONS KR \& OREM WH. 2000. Use of ${ }^{234} \mathrm{U}$ and ${ }^{238} \mathrm{U}$ isotopes to identify fertilizer-derived uranium in the Florida Everglades. Appl. Geochemistry 15: 360-383. 


\section{NOTAS SOBRE OS AUTORES}

Valter Antonio Becegato é Engenheiro Agronômo (UDESC-1988), Mestre em Ciência do Solo (UFPR-1999), Doutor em Geologia Ambiental (UFPR-2005). Trabalhou na Usina Hidrelétrica de Itaipu Binacional de 1979 a 1982, Setor de Desapropriação. É professor desde 1990 da Universidade do Estado de Santa Catarina (UDESC), Centro de Ciências Agroveterinárias/Campus III, Lages-SC, onde ministra disciplinas de interpretação de imagens para análise ambiental, informática aplicada e certificação ambiental.

Francisco José Fonseca Ferreira é Geólogo (UFPE-1970), Especialista em Geofísica Aplicada (UFBA-1974), Mestre e Doutor em Ciências (USP-1982; USP1991), com atuação profissional na CPRM (1972-1980) e no IPT (1981-1990). Desde 1992 é Professor Adjunto do Departamento de Geologia da UFPR, onde ministra disciplinas de geofísica aplicada nos cursos de graduação e pós-graduação. A partir de 1998 coordena o Laboratório de Pesquisas em Geofísica Aplicada - LPGA/UFPR, onde desenvolve pesquisas aplicadas à cartografia geológica e pedológica, exploração mineral e de águas subterrâneas e ao meio ambiente. 